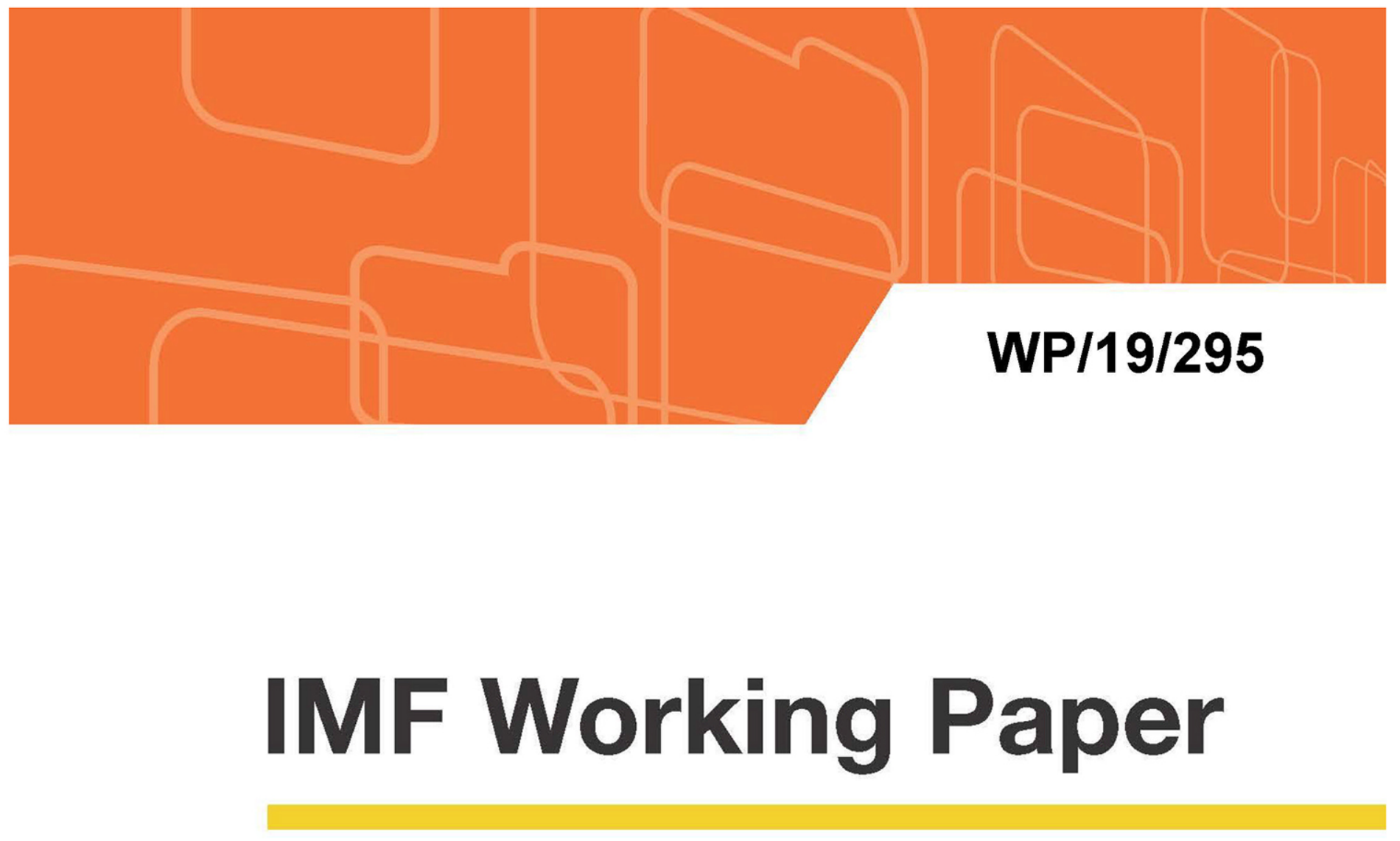

\title{
Post-Crisis Changes in Global Bank Business Models: A New Taxonomy
}

by John Caparusso, Yingyuan Chen, Peter Dattels, Rohit Goel, and Paul Hiebert

IMF Working Papers describe research in progress by the author(s) and are published to elicit comments and to encourage debate. The views expressed in IMF Working Papers are those of the author(s) and do not necessarily represent the views of institutions of affiliated authors, including the IMF, its Executive Board, or IMF management.

I N T E R N A T I O N A L M O N E T A R Y F U N D 


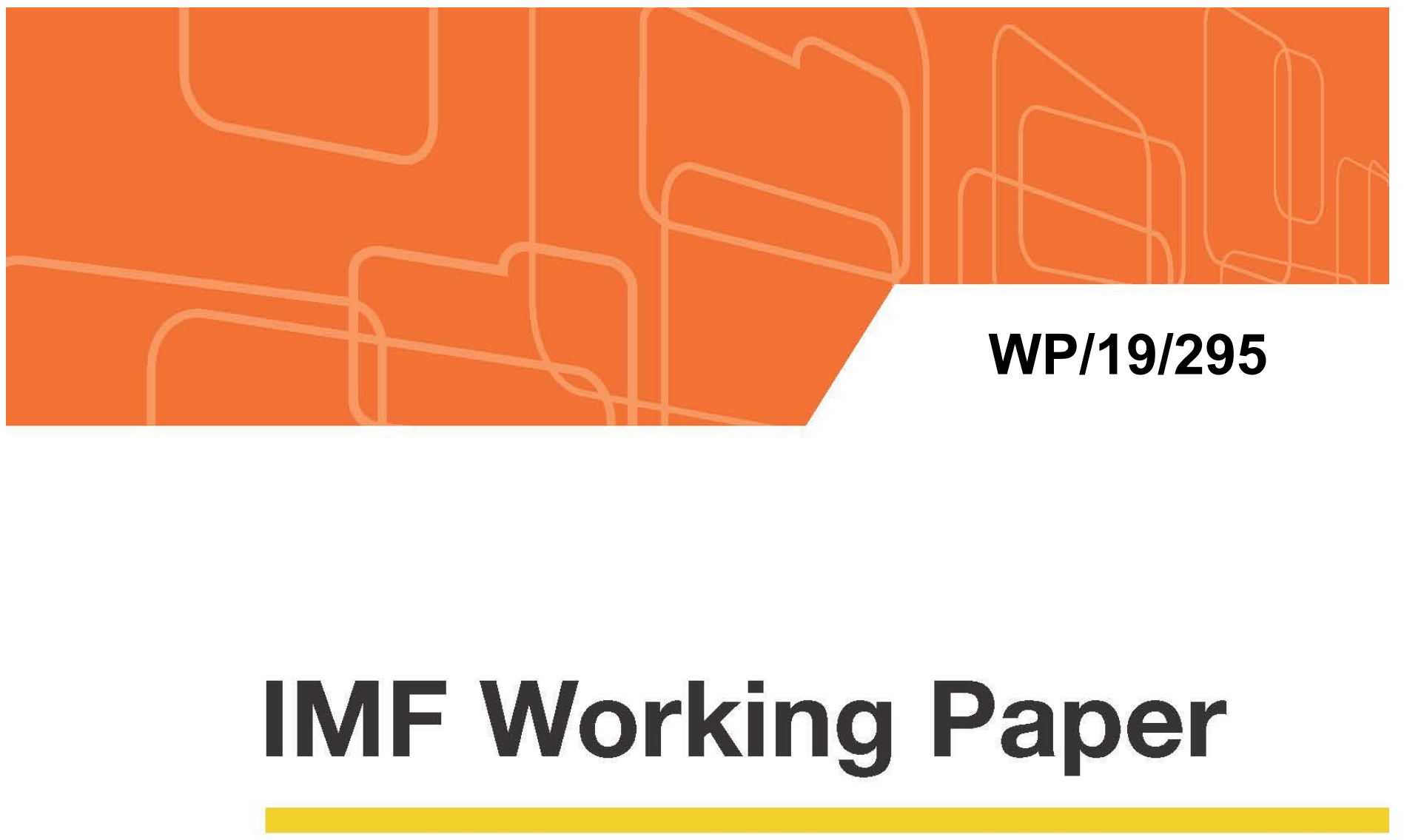

\section{Post-Crisis Changes in Global Bank Business Models: A New Taxonomy}

by John Caparusso, Yingyuan Chen, Peter Dattels, Rohit Goel, and Paul Hiebert

IMF Working Papers describe research in progress by the author(s) and are published to elicit comments and to encourage debate. The views expressed in IMF Working Papers are those of the author(s) and do not necessarily represent the views of institutions of affiliated authors, including the IMF, its Executive Board, or IMF management.

I N T E R N A T I O N A L M O N E T A R Y F U N D 


\title{
IMF Working Paper
}

Monetary and Capital Markets Department

\section{Post-Crisis Changes in Global Bank Business Models: A New Taxonomy ${ }^{1}$ \\ Prepared by John Caparusso, Yingyuan Chen, Peter Dattels, Rohit Goel, and Paul Hiebert}

Authorized for distribution by Anna Ilyina

December 2019

IMF Working Papers describe research in progress by the author(s) and are published to elicit comments and to encourage debate. The views expressed in IMF Working Papers are those of the author(s) and do not necessarily represent the views of the IMF, its Executive Board, or IMF management.

\begin{abstract}
The Global Financial Crisis unleashed changes in the operating and regulatory environments for large international banks. This paper proposes a novel taxonomy to identify and track business model evolution for the 30 Global Systemically Important Banks (G-SIBs). Drawing from banks' reporting, it identifies strategies along four dimensions -consolidated lines of business and geographic orientation, and the funding models and legal entity structures of international operations. G-SIBs have adjusted their business models, especially by reducing market intensity. While G-SIBs have maintained international orientation, pressures on funding models and entity structures could affect the efficiency of capital flows through the bank channel.
\end{abstract}

JEL Classification Numbers: G15, G21, L21, F39.

Keywords: International banks, Business model, Bank performance, Global Financial Stability, Regulation

Author's E-Mail Address: jcaparusso@imf.org, ychen@,imf.org,pdattels@imf.org, rgoel@imf.org, paul.hiebert@,ecb.int

\footnotetext{
${ }^{1}$ The authors acknowledge helpful comments from Nina Biljanovska, Ljubica Dordevic, Will Kerry, Paola Morales, Mustafa Saiyid and Tomohiro Tsuruga. Some results first appeared in the IMF's October 2017 Global Financial Stability Report, and the authors are grateful for early feedback from several members of the IMF's Monetary and Capital Markets Department.
} 
I. Introduction .$\underline{4}$

II. Business Model Taxonomies $\underline{6}$

A. Building the Framework-Lines-of-Business and Geographic Orientation..............

B. International Business Model Structures........................................................... 10

III. How Has the Global Financial Crisis Reshaped Bank Business Models?....................... 13

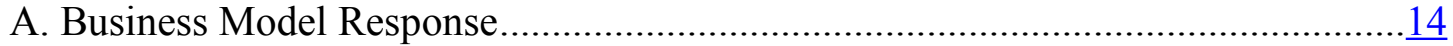

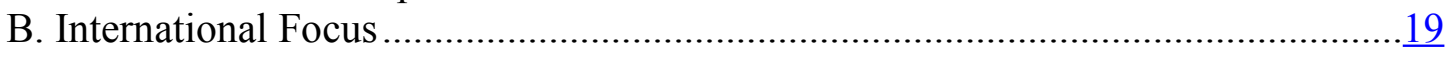

IV. Emerging Pressures on International Banking Models .............................................21

A. International Wholesale Banking Model: Challenged .....................................

B. International Consumer Banking - Lower Profitability than

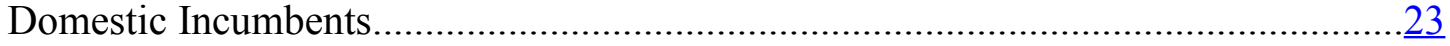

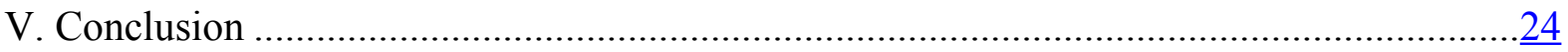

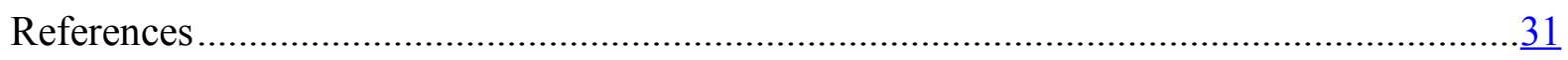

\section{Figures}

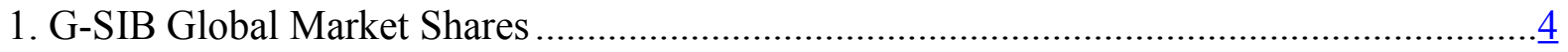

2. Four Dimensions of Business Model Framework ......................................................

3. Classification of Business Models from Line-of-Business Revenue Mix ........................... $\underline{8}$

4. G-SIBs Line-of-Business Strategies: Revenue by Business Lines .................................. $\underline{8}$

5. Classification of Geographic Orientation .................................................................... $\frac{9}{9}$

6. G-SIBs Geographic Orientation: Revenue by Geographic Region .................................. $\underline{9}$

7. Business Models: Line-of-Business Strategy and Geographic Orientation........................10

8. International Business Models Mapped to Wholesale and Retail ...................................11

9. Selected G-SIBs: Customer Focus and Funding Model ..............................................12

10. Liabilities Mix —Foreign Bank Branches and Subsidiaries.......................................... 12

11. Selected G-SIBs: Degree of Subsidiarization ..........................................................13

12. G-SIBs: Return on Equity ............................................................................. 13

13. Profitability Dynamics by Business Model and by Line of Business .............................15

14. G-SIBs' Line of Business Revenue Mix, 2005-07 versus 2016-18 ................................15

15. G-SIBs: Migration between Business Model during the Post-Crisis Period....................16

16. Line of Business Trends.........................................................................................

17. G-SIB Strategic Stabilization: Sharp Slowdown in Aggregate Growth and

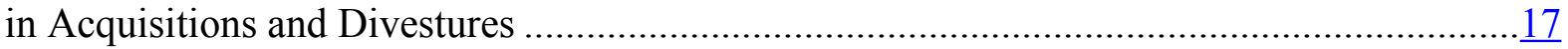

18. G-SIB Market Risk Intensity ........................................................................ 18

19. Share of G-SIB Assets in Each Profitability Range.................................................. 18

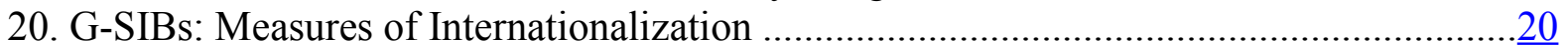

21. Intra-Group Transfers by US Offices of Foreign Banks............................................... 
22. Foreign Bank Branches' Intragroup Positions and Flows

23. G-SIBs' Overseas Bank Subsidiaries Average Performance Against Domestic Peers ..... 24

\section{Annexes}

1. List of G-SIBs . $\frac{27}{28}$

2. Breakdown of Market Intensity and Internationality Measures .$\underline{28}$

3. Group Structure Measure.... 


\section{INTRODUCTION}

The Global Financial Crisis (GFC) represents a watershed for the banking sector, marked by an overhaul of the regulatory framework, long lasting changes to the economic and financial environment, as well as shifts in the competitive landscape for financial services. As global banks adapt to the new environment, including sharp declines in financial performance, the resulting shifts in financial intermediation across product lines and geographies are relevant for global financial stability. To better understand how banks themselves are adapting their business models and adjusting lines of business that could have substantive impact on the provision of financial services, we develop a novel taxonomy of bank business models.

Current classifications ${ }^{2}$ tend to be based on statistical methodologies such as cluster analysis and regulatory classifications, suited to classifying large heterogeneous groups of banks into a broad business model classes based on a few balance sheet and income statement ratios. These embed many attractive features to capture prudential or systemic risk attributes but are less attuned to shifts in granular bank business strategies focused on the various dimensions of business model mix specific to G-SIBs. The methodology developed in this paper designed to leverage banks' own reporting to track evolution of these main business model aspects - from main revenue drivers, to geographic orientation, to other operating information characterizing banks' strategies. This use of granular bank reporting well beyond the standard consolidated financial statements, allows us to measure shifts in bank strategies and business models in ways that are also consistent with managements' strategic intentions. Although this paper does not apportion the forces driving changes in business models, the bottom-up approach facilitates a mapping of changes at the bank level to broader shifts in the global banking system that are relevant to global financial stability.

This paper focuses on G-SIBs. Despite significant business shifts and exits from activities since the GFC, they continue to play a crucial role in the glob al financial system. The 30 banks currently designated as G-SIBs have maintained dominant positions in the international banking system. ${ }^{3}$ These banks together hold more than $\$ 50$ trillion in assets and account for more than one-third of the global banking system's total assets and loans. They play an essential role in international capital market services, the international financial infrastructure, and international lending activities. In several of these product markets, they collectively comprise 75 percent or more global market shares. (Figure 1).

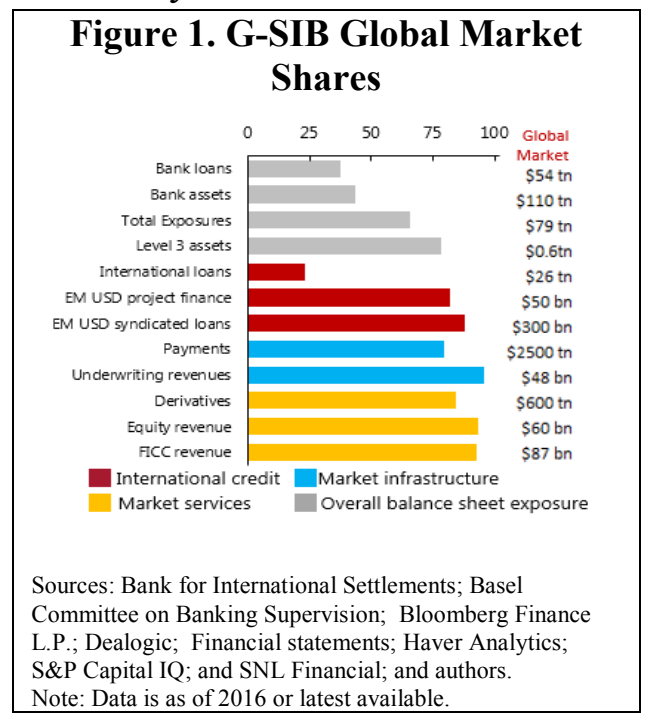

\footnotetext{
2 See, for instance Altavilla et al (2019), Ayadi et al (2011, 2012 and 2016), Choi et al (2018), Emter et al (2018), Everett et al (2019), Fame and Voludis (2017), Herzberg et al (2019), Kok et al (2016), McCauley et al (2019), Merck Martel et al (2012), and Roengpitya et al (2014 and 2017).

${ }^{3}$ In this paper we use the list of G-SIBs identified in 2018 (see Table A.1 in Annex 1).
} 
With this collective dominance, G-SIBs remain central to the provision of global financial services and the stability of the global financial system.

The taxonomy exploits detailed bank data to identify bank business models along four dimensions. We measure group-wide strategy along on two metrics-(i) line of business mix (based on revenues by business lines) and (ii) geographic orientation (based on local and global footprint) - then further classify international activities into wholesale and retail banking strategies based on (iii) funding mix and (iv) legal entity (subsidiary or branch) structure. To sort each bank into strategy buckets consistent with managements' description of their own business models, we set thresholds to classify bank business line-of-business models into six categories (wealth manager, transaction bank, investment bank, consumer bank, corporate bank, and universal bank) and geographic strategies into three groups (global, regional and local). Methodologies and data sources are detailed in Section II.

Section III examines how banks have adapted and reshaped their business models in the wake of the financial crisis. A premise of the paper is that banks might adjust their lines of business mix within their business model or even migrate to a new model as they seek higher sustainable profitability. The extent of those adjustments is examined, as well as the degree to which banks have reduce risky market exposures and activities. Given the important role of GSIBs in cross border lending and credit, the business model framework also sheds light on whether such global activity has declined, an important consideration for the efficient functioning of the global financial system.

Section IV examines emerging pressures and future challenges of international banking models of GSIBs. Information from G-SIBs' international subsidiaries and branches is used to assess how international personal financial services (PFS) and wholesale models are being affected by regulatory developments and the rising competitiveness of local players. ${ }^{4}$

The paper concludes in Section V with some key observations.

- Banks have made substantial adjustments in bank business models in the wake of the GFC. According to our classifications, eight G-SIBs (over one quarter) have altered their business mix sufficient to migrate to a different business model. Changes along business lines have broadly been in line with the thrust of strengthened regulation aimed at reducing systemic risk. This has been particularly evident in the provision of capital market services - using measures developed in this paper, market risk intensity has declined from pre-crisis by roughly half.

- As a group, G-SIBs have maintained their degree of international orientation, providing evidence that unintended consequences of diminished international activity in credit and lending have been avoided.

\footnotetext{
${ }^{4}$ This builds on the literature of De Haas and van Lelyveld 2010 and 2011, De Haas and van Horen (2013), Fiechter et al (2011), Forbes et al (2014), Gambacorta et al (2017), Ichue and Lambert (2016), Kerl and Niepmann (2016), Lambert et al (2015), McCauley et al (2010), Lumpkin and Yokoi-Arai (2017), and Quoirez (2017).
} 
- G-SIB models continue to evolve as these banks address emerging challenges to entity structures and funding models in their international operations. The international wholesale model may be most vulnerable given its reliance on the flexible cross-border flow of wholesale funding among international branches as regulation and ringfencing may inhibit cross border liquidity flows, along with increased emphasis on subsidiarization.

\section{BUSINESS Model TAXonomies}

The 30 banks currently designated as G-SIBs display enormous diversity. Their line-ofbusiness models range from more narrowly focused transaction banks and wealth managers to universal banks that provide a wide range of financial services. G-SIBs include mainly international banks, but also several large domestic banks with relatively small international operations confined to selected business lines (for example, capital markets). Differences in business lines - for example corporate banking versus personal financial services $\left(\mathrm{PFS}^{5}\right.$ ) may also determine differences in the way international operations are funded and legal entity (subsidiary versus branch) structures.

We develop a bank business model framework that captures four dimensions (Figure 2):

(1) lines-of-business;

(2) geographic orientation;

(3) international funding structure; and

(4) entity (branches and subsidiaries) structure of foreign operations.

Dimension one and two above are based on consolidated (global) level reporting. Three and four draw on consolidated financials, regulatory filings, and entity level data from G-SIB's international subsidiaries and branches.

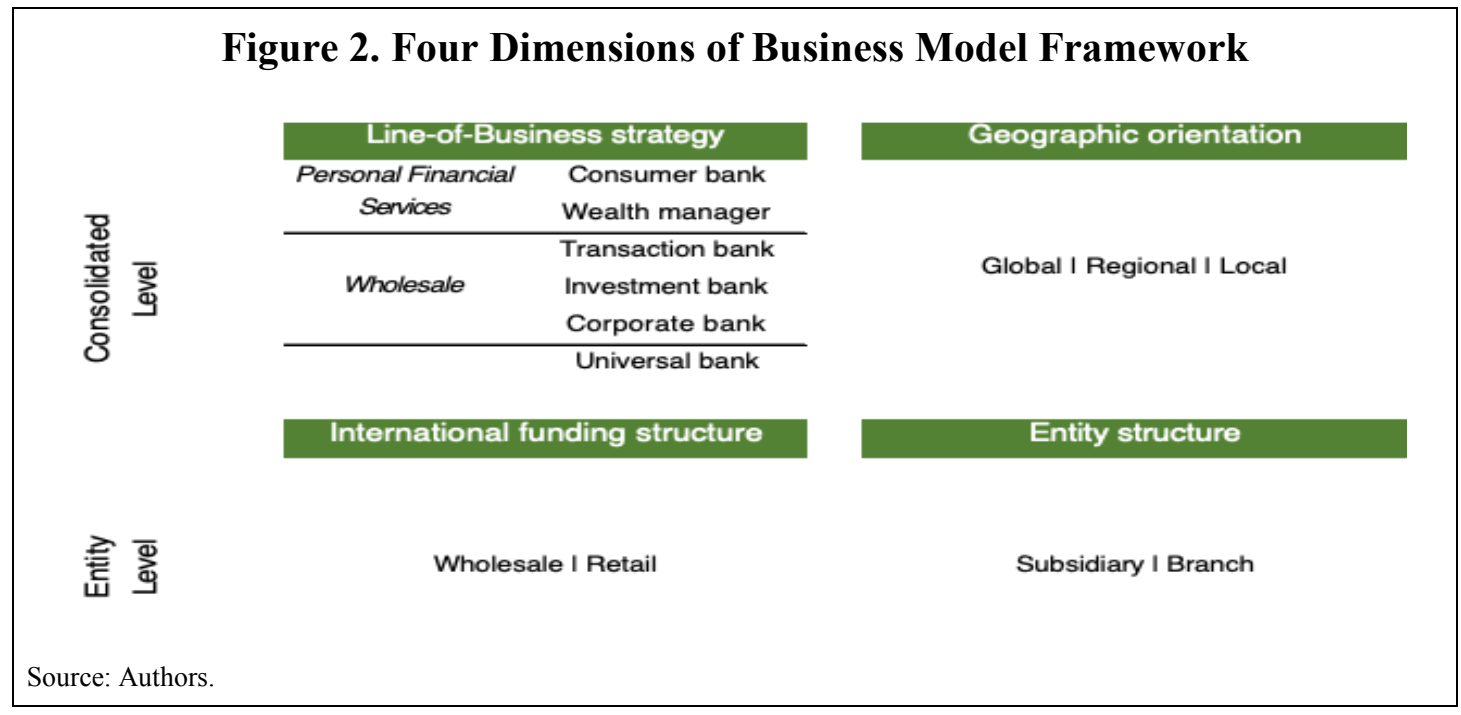

\footnotetext{
5 'Personal financial services' includes retail banking and wealth management.
} 


\section{A. Building the Framework-Lines-of-Business and Geographic Orientation}

The first dimension of our business model framework is the line-of-business strategy identified by banks' own reporting in their financial statements bolstered by management presentations. These reports provide information on revenues along business lines. We use available line-of-business revenue (or asset) data to group bank revenues into six line of business categories based on banks' revenue mix mapped against chosen partition thresholds:

1. Consumer banking: predominantly PFS banking, mainly for households.

2. Wealth management: private banking, funds management and insurance.

3. Commercial banking: lending to small and medium-sized companies (note that many banks allocate this across corporate and consumer banking).

4. Corporate banking: lending to corporate customers, particularly large corporates. Many banks also include in this category investment banking services such as underwriting and corporate advisory. ${ }^{6}$

5. Markets: include both revenues from brokerage across all instruments (equities, fixed income, currencies, commodities), and related gains and losses on trading positions.

6. Transaction services: include payments, cash management and settlement and clearing services, mainly for corporate and financial institution customers.

Specifically, we define three 'narrow' business models - wealth manager, transaction bank and investment bank - to describe firms that derive at least half of their revenues from a single line of business. ${ }^{7}$ Related but separate lines of business are grouped to define somewhat broader business models. Banks whose consumer banking plus wealth management constitute more than three-quarters of revenue are grouped under the consumer bank business model, and banks whose corporate banking plus commercial banking revenues constitute more than three-quarters revenue are grouped under corporate bank business model. Finally, many G-SIBs are classified as universal banks as they service both retail and corporate customers across a wide range of services and therefore generate a broad distribution of revenues across business lines, with low concentration in any specific area (Figure 3). It is important to note thresholds are chosen that broadly align with banks' own description of their business models. Setting the same thresholds across all banks allows for aggregation and grouping into specific business models.

\footnotetext{
${ }^{6}$ These revenue pools are typically much smaller than corporate banking services. Therefore, revenues from the markets business, rather than revenues from corporate banking (even when labelled 'corporate and investment banking'), are the key identifier of the investment banking business model.

${ }^{7}$ For investment banks, we include both corporate banking and markets, which are tightly linked in the investment banking model, if the bank derives at least a quarter of its revenues from markets activities.
} 
Figure 3. Classification of Business Models from Line-of-Business Revenue Mix

\begin{tabular}{|lll|}
\hline \multicolumn{1}{|c|}{ Business Model } & \multicolumn{1}{c}{ Revenues from Business Lines Considered } & $\begin{array}{c}\text { Threshold } \\
\text { (Percent of } \\
\text { consolidated revenue) }\end{array}$ \\
\hline Wealth manager & Wealth management & $>50$ \\
\hline Transaction bank & Transaction services & $>50$ \\
\hline Investment bank & Corporate and investment banking plus Markets & $>50$ \\
\hline Consumer bank & AND Markets alone & $>25$ \\
\hline Corporate bank & Corporate banking plus commercial banking & $>75$ \\
\hline Universal bank & Either, PFS banking and corporate banking & Each $>40$ \\
\cline { 2 - 3 } & OR, more than three lines of business & Each $>20$ \\
\hline Source: Authors. & & \\
\hline
\end{tabular}

This approach partitions the 30 G-SIBs into several groupings: three smaller clusters of narrower strategies (investment banks, transaction banks and wealth managers), two clusters of broader strategies ( 4 corporate banks and 8 consumer banks), and a large cluster of 12 universal banks (Figure 4).

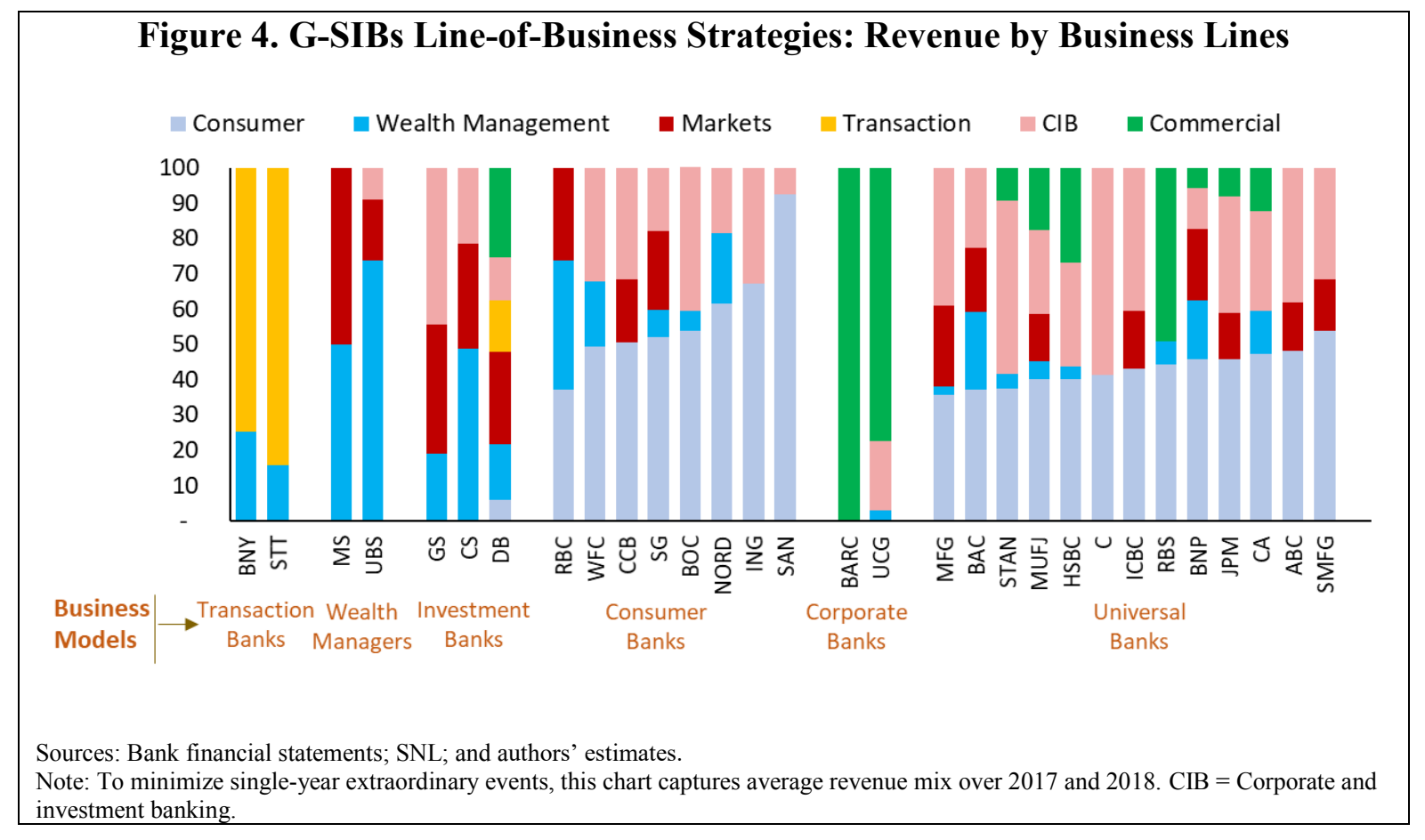


The second dimension of our business model framework is geographic orientation. We use financial disclosure of revenue mix by geographic region to group G-SIBs into local, regional or global strategies (Figure 5). First each bank's revenues are split between its home market and revenues by four broader geographic regions (North America; Europe, Middle East and Africa; Latin America; and Asia-Pacific). Thresholds are then set to classify geographic orientation. Specifically, local banks are those that derive more than 80 percent of revenues from their home country. Global banks generate significant revenues across two or three broad regions. 'Regional' banks are those which are neither local nor global and derive a high proportion of revenues from their home region.

\begin{tabular}{|c|c|c|}
\hline \multicolumn{3}{|c|}{ Figure 5. Classification of Geographic Orientation } \\
\hline Geographic Scope & $\begin{array}{l}\text { Revenue by Geographic Region } \\
\text { Considered }\end{array}$ & $\begin{array}{c}\text { Threshold } \\
\text { (Percent of consolidated revenue) }\end{array}$ \\
\hline Local & From domestic market & $>80$ \\
\hline Global & $\begin{array}{l}\text { Either, from two regions } \\
\text { Or, from three regions }\end{array}$ & $\begin{array}{l}\text { Each }>10 \\
\text { Each }>5\end{array}$ \\
\hline Regional & $\begin{array}{l}\text { From domestic market } \\
\text { And, from home region } \\
\text { And, not considered as global bank }\end{array}$ & $\begin{aligned} &<80 \\
&>50 \\
& \text { Bank is not Global }\end{aligned}$ \\
\hline \multicolumn{3}{|c|}{$\begin{array}{l}\text { Source: Authors. } \\
\text { Note: 'Regions' in this framework refers to four broad geographic areas: North America; Europe, Middle East and Africa; Latin } \\
\text { America; and Asia-Pacific. }\end{array}$} \\
\hline
\end{tabular}

Nearly two-thirds of G-SIBs are global (Figure 6). Some banks (for example, Standard Chartered and HSBC) have no readily identifiable single 'home' market. There are also several local banks included among the G-SIBs mainly due to their size (Chinese banks, Bank of America and Wells Fargo in the US). Between these two extremes, there is considerable heterogeneity.

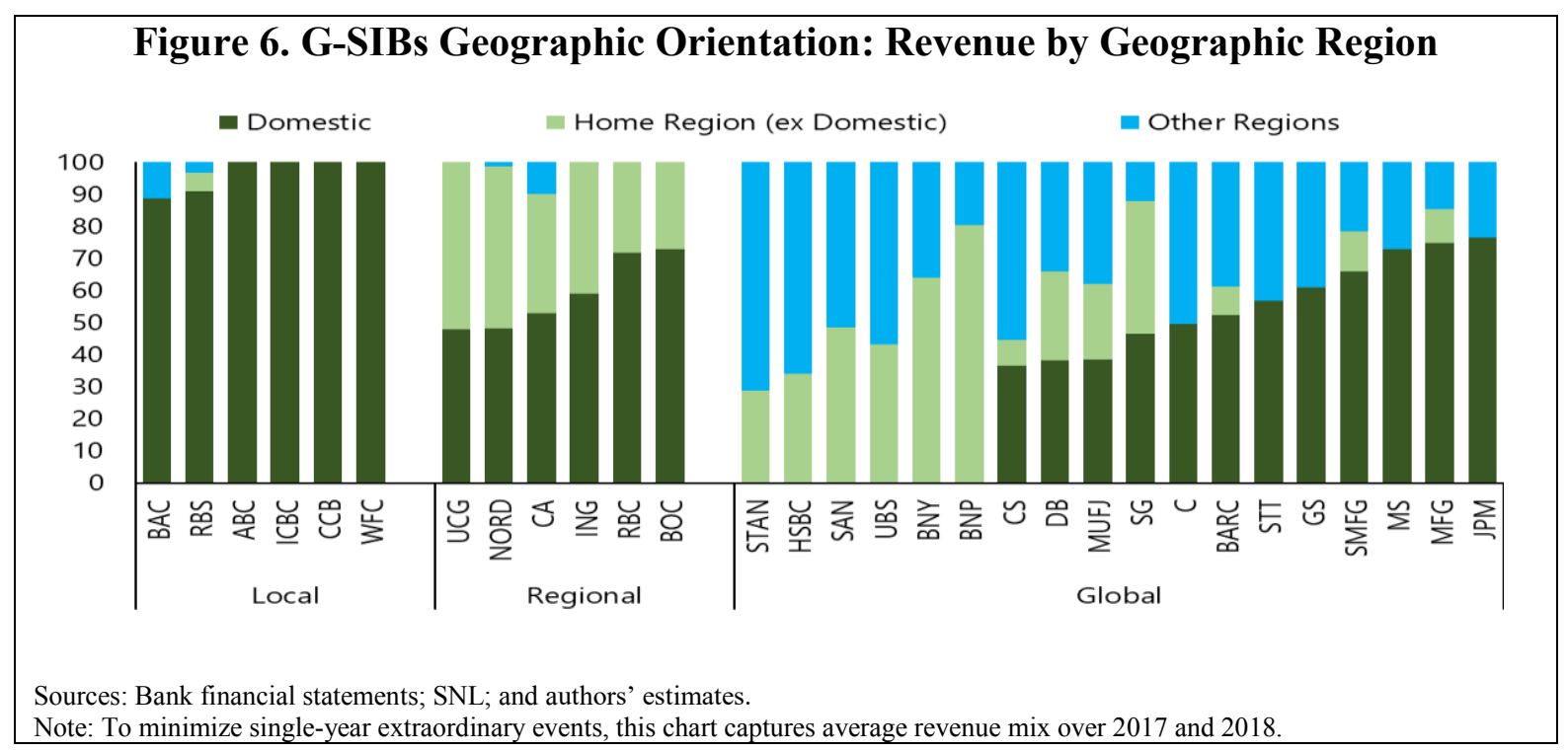


Figure 7 presents a summary of the classification of 30 G-SIBs by combining the two dimensions above, along with the total assets ascribable to each group. Using this grouping of business models, more than half of G-SIB assets are universal banks, followed by a quarter of assets in consumer banks. Banks with narrower strategies account for less than 20 percent of G-SIB assets. From the geographic perspective, global banks account for about half of G-SIB assets, while a third of G-SIB assets are local banks and a fifth regional banks.

\begin{tabular}{|c|c|c|c|c|}
\hline \multirow{3}{*}{$\begin{array}{c}\text { Figure } 7 . \text { Busi } \\
\qquad \begin{array}{c}\text { Line of } \\
\text { Business }\end{array}\end{array}$} & $\begin{array}{r}\text { ness Models } \\
\text { Geograpl }\end{array}$ & $\begin{array}{l}\text { Line-o } \\
\text { lic Orier }\end{array}$ & $\begin{array}{l}\text {-Business } \\
\text { tation }\end{array}$ & Strategy \\
\hline & \multicolumn{3}{|c|}{ Geographic Reach } & \multirow{2}{*}{$\begin{array}{c}\text { Percent of GSIB } \\
\text { assets }\end{array}$} \\
\hline & Global & Regional & Local & \\
\hline Universal Bank & $\begin{array}{c}\text { C, JPM, HSBC, STAN, } \\
\text { BNP, MUFJ, MFG, } \\
\text { SMFG }\end{array}$ & $C A$ & $\begin{array}{c}B A C, \text { RBS, ABC, } \\
I C B C, C C B\end{array}$ & 62.2 \\
\hline Consumer Bank & SAN, SG & $\begin{array}{l}\text { RBC, ING, } \\
\text { NORD, BOC }\end{array}$ & WFC & 22.4 \\
\hline Corporate Bank & BARC & UCG & & 4.6 \\
\hline $\begin{array}{c}\text { Investment } \\
\text { Bank }\end{array}$ & $G S, C S, D B$ & & & 6.2 \\
\hline $\begin{array}{c}\text { Wealth } \\
\text { Manager }\end{array}$ & MS, UBS & & & 3.5 \\
\hline $\begin{array}{c}\text { Transaction } \\
\text { Bank }\end{array}$ & BNY, STT & & & 1.2 \\
\hline $\begin{array}{c}\% \text { of GSIB } \\
\text { Assets }\end{array}$ & 51.7 & 18.1 & 30.2 & 100.0 \\
\hline
\end{tabular}

\section{B. International Business Model Structures}

The line of business discussion above is based on G-SIBs' consolidated revenue business mix. However, many G-SIBs build separate and different models between domestic and international operations. ${ }^{8}$ For this reason, assessment based on consolidated information can be misleading. Distinguishing between domestic and international models requires an identification of the structure of G-SIBs' international business models.

Specifically, we differentiate G-SIBs' international models based on funding structures (retail deposits vs. wholesale instruments) and entity structure (branches vs. subsidiaries), (Figure 8). These two dimensions are related. Banks form subsidiaries in overseas markets mainly to tap local deposits; and those that rely on wholesale funding for international operations typically value the liquidity management and operational flexibility of foreign branch offices.

\footnotetext{
${ }^{8} \mathrm{G}$-SIBs can have vastly different business models between their domestic and international operations. For example, Bank of America, JPMorgan, Deutsche Bank and Credit Agricole are universal or consumer banks on a consolidated level but are wholesale (wholesale, investment or transaction) banks internationally.
} 


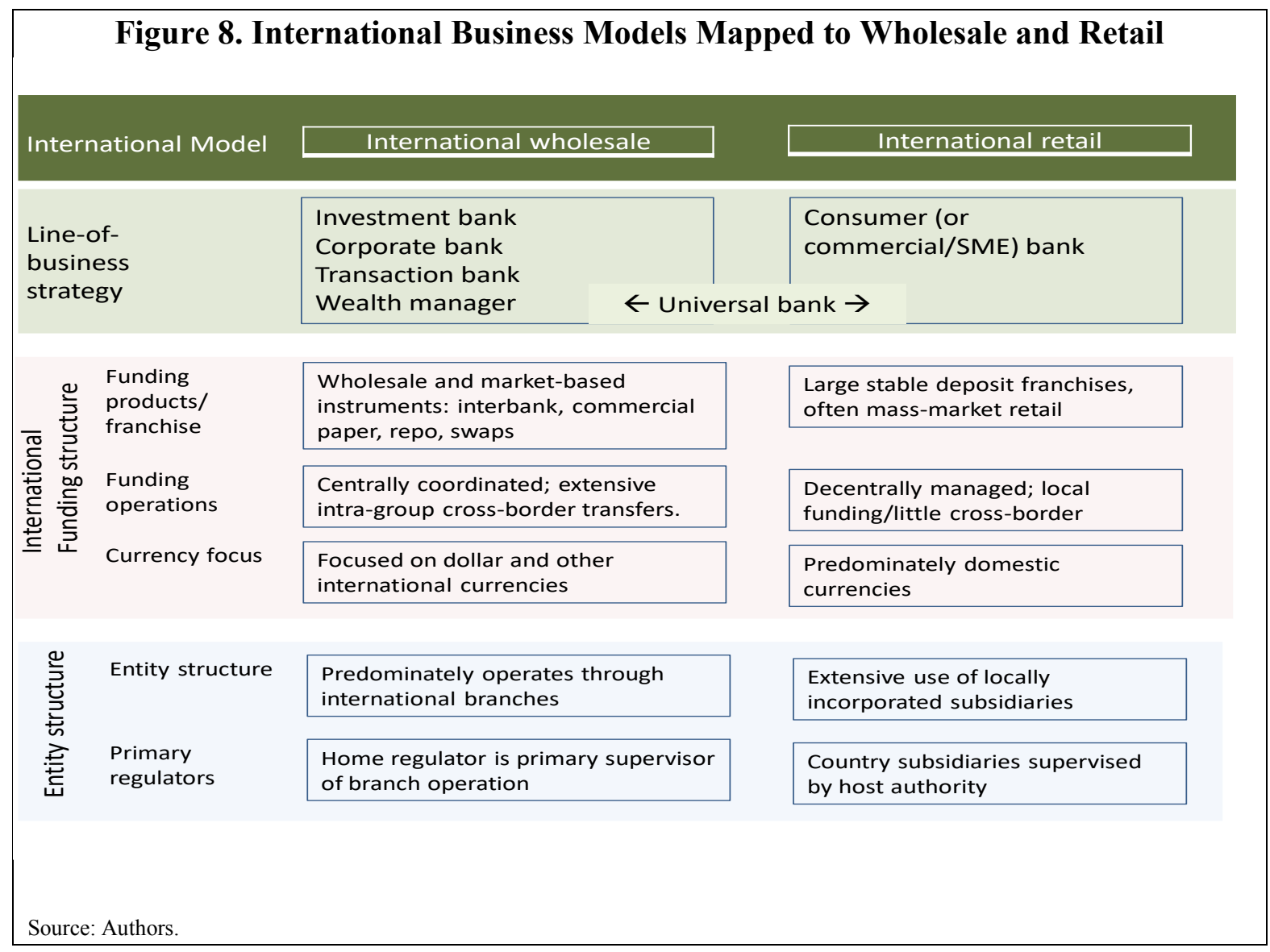

\section{Funding structure}

Banks' international businesses typically follow one of two basic models-wholesale or PFS (Figure 8) (BCBS 2010, 2012; Gambacorta et al 2017; McCauley and McGuire 2010). PFS models depend relatively heavily on 'local' funding - mainly local-currency deposits from host-country sources - to meet overall funding needs outside their home market. In contrast, corporate-oriented ('international wholesale') models pursue more 'centralized' funding approaches that rely more on sources outside their host countries. Evidence presented in Figure 9, panel 1 confirms these differences. Liquidity management may also be centralized for foreign currency funding to serve corporates with cross-border Treasury and transaction services (McCauley, McGuire and von Peter 2010; CGFS 2010a, CGFS 2010b).

Wholesale banks depend more heavily on intra-group funding as an efficient mechanism to shift liquidity across countries. Figure 9 panel 2, highlights that wholesale banks with substantial market operations (for example, DB and BARC) rely relatively heavily on intragroup funding. International banks' access to internal funding is particularly important during periods of local stress (Cetorelli and Goldberg 2010 and 2016, Reinhardt and Riddiough 2014, Kerl and Niepmann 2016). 
Figure 9. Selected G-SIBs: Customer Focus and Funding Model

1. Customer Focus and Funding Localization

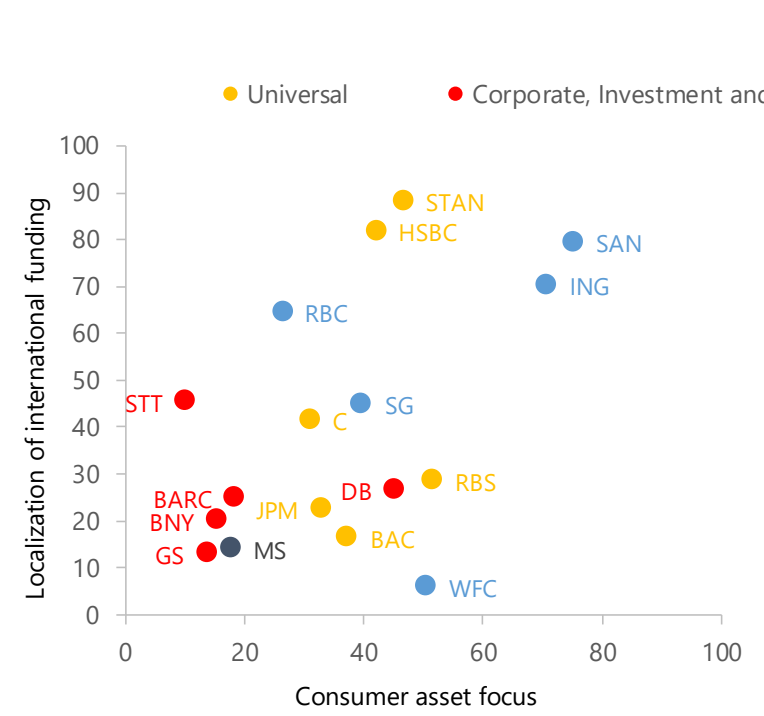

2. Funding Localization and Intra-Group Funding as a Share of Foreign Liabilities

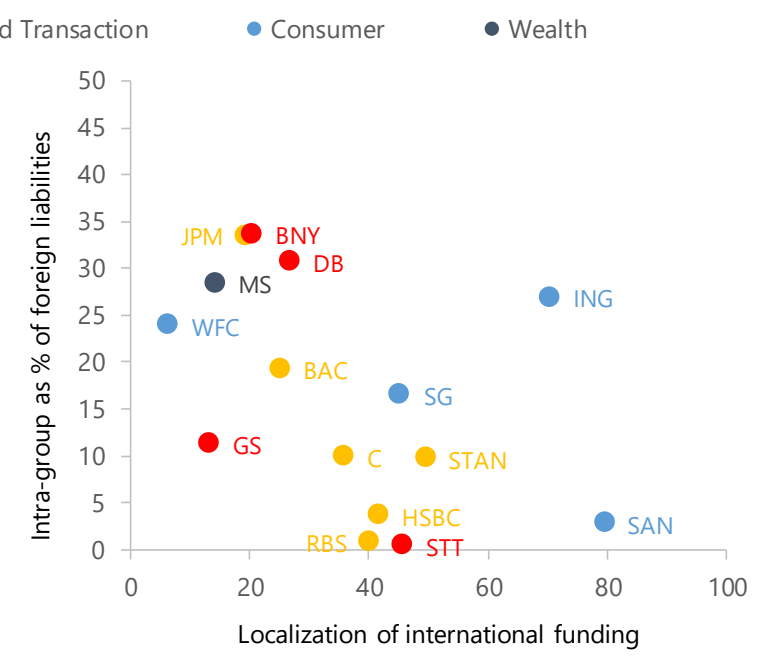

Sources: Bank consolidated and subsidiary financial statements; Federal Reserve Form Y-15; G-SIB assessment filings; authors' analysis.

Note: Localization of international funding = Foreign offices' local liabilities in local currency as a percent of consolidated total foreign liabilities. Consumer asset focus $=$ Global loans to households as percent of total assets (There is insufficient data to measure banks' consumer loans outside their home jurisdictions.). All magnitudes are based on group consolidated disclosure. Banks in Switzerland, Japan and China are excluded due to insufficient granularity of G-SIB data submissions from publicly available sources.

\section{Entity structure}

Entity structure is generally linked to funding strategies. Foreign subsidiaries allow access to local deposits; most regulators allow banks to tap insured deposits only through local subsidiaries (Figure 10, panel 1). Branches are more wholesale funded (Figure 10, panel 2).

\section{Figure 10. Liabilities Mix_Foreign Bank Branches and Subsidiaries}

\section{Foreign Bank Subsidiaries}

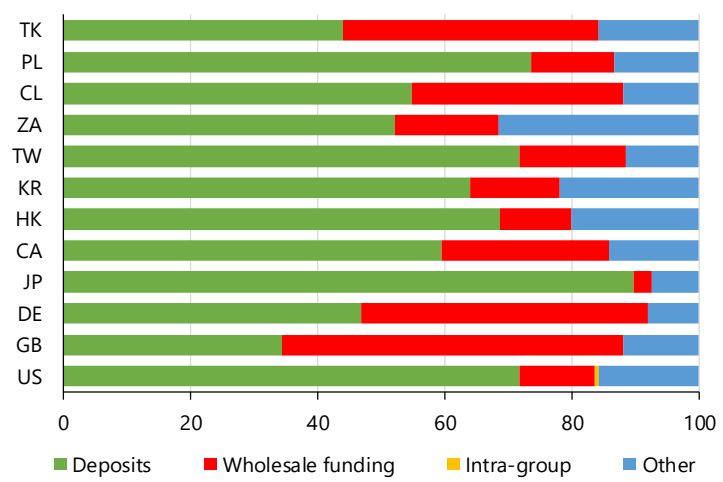

\section{Foreign Bank Branches}

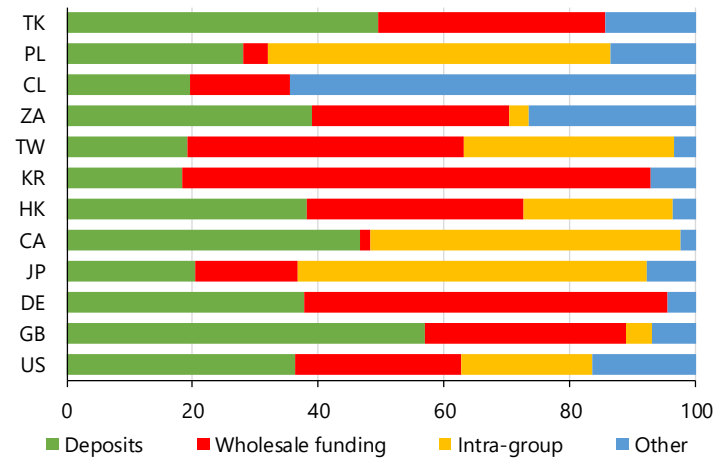

Sources: Bank financial statements; KPMG; national authorities; SNL Financial; and authors' estimates and analysis. Note: Countries are identified by two-letter ISO codes. 'Other' items include non-funding items such as payables. 
Figure 11, panels 1 and 2 suggest that international consumer business models tend to be more heavily subsidiarized and rely more on local funding, while international wholesale models are more branch-based and rely less on local deposits. In the wake of the financial crisis, these models and entity structures face news challenges discussed in Section IV.

\section{Figure 11. Selected G-SIBs: Degree of Subsidiarization}

1. Subsidiarization and Global Consumer Intensity
2. Subsidiarization and Localization of International Funding
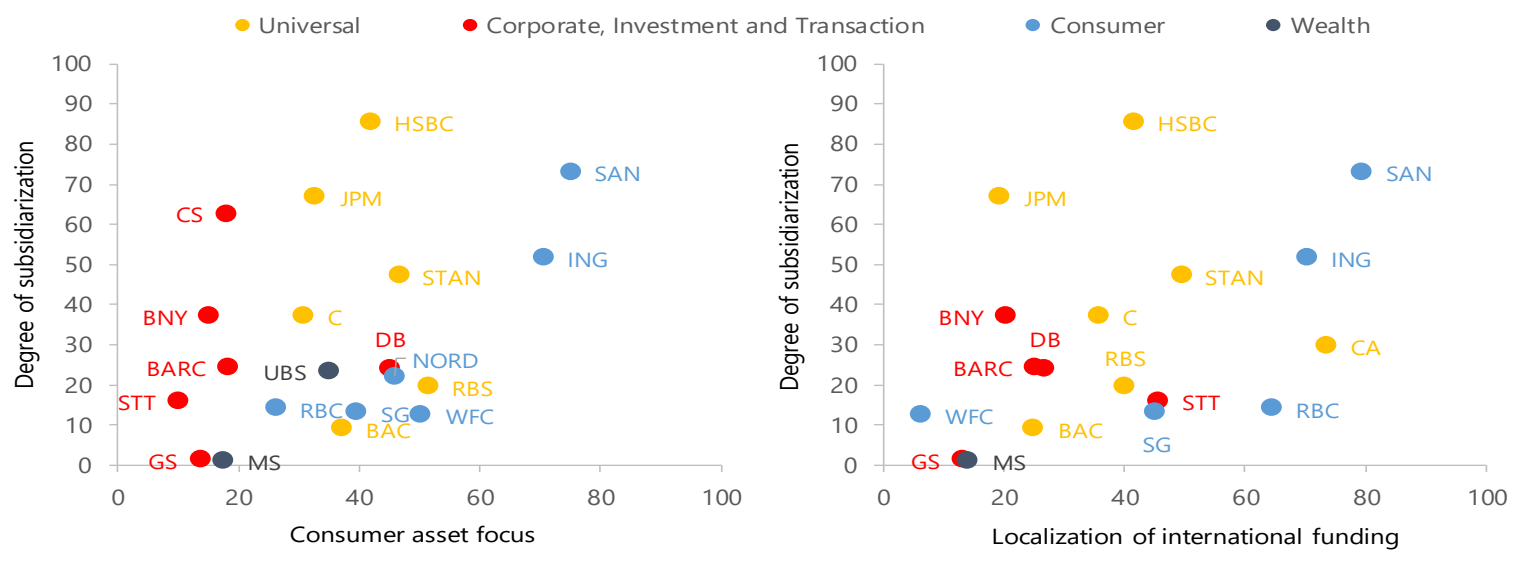

Sources: SNL, bank financial statements; US Federal Reserve Board; and authors' estimates and analysis. Note: Degree of subsidiarization $=$ Assets of material banking subsidiaries as percent of consolidated assets.

\section{How Has the Global Financial Crisis Reshaped Bank Business Models?}

The Global Financial Crisis (GFC) represents a watershed for the banking sector, marked by an overhaul of the regulatory framework, long lasting changes to the economic and financial environment, as well as shifts in the competitive landscape for financial services. One of the benefits of the taxonomy presented in this paper is that it provides insights into how bank business models have been reshaped and adjusted to these pressures and structural changes.

G-SIBs faced a complex set of challenges and earnings shocks (Figure 12). Bad debt and losses on trading and investment positions materialized, while many US and European G-SIBs have faced large (often multi-billion dollar) penalties and other legal charges stemming from illegal or inappropriate conduct. The GFC also left in its wake sustained low interest rates, that compressed interest income, as well as dampened market volatility that suppressed trading volumes and therefore revenues.

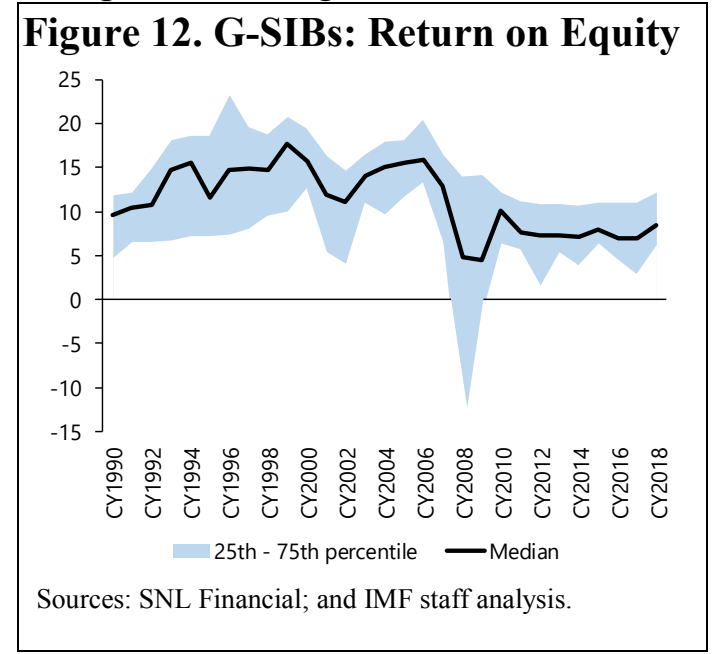


A strengthened global capital framework (Basel III) was accompanied by a new and more stringent global liquidity management regime. National or regional regulators introduced new frameworks for total loss-absorbing capital (TLAC), ${ }^{9}$ intended to reduce the likelihood of government bailouts. Supervisors have implemented vastly enhanced stress-testing processes, to bolster bank resilience, and new resolution regimes, to manage failed banks. Regulators have also introduced measures - increased risk-asset weightings for capital market activities, capital charges related to the fundamental review of the trading book, simple leverage ratios and others - to better align banks' capital against their risk exposures. These regulatory changes forced a review by banks of their business models, especially for investment and corporate banking operations.

These developments reshaped profitability dynamics along business lines and across the GSIB cohort. Various measures of profitability were examined. The best measure of 'deleveraged' operating profitability, Pretax Return on Assets (ROA) — a good measure of unleveraged operating profitability — suggests that underlying profitability trends were mixed across businesses. Wealth management and consumer banking remained relatively profitable during the crisis period and aftermath, while both corporate and investment banking generated sub-standard profitability, both before the financial crisis and more recently (Figure 13, panel 1). However, using the average return on equity measure of profitabilitywhich incorporates the impact of regulation-induced deleveraging-illustrates severe profitability pressure among firms whose strategies are focused on corporate banking and markets activities (Figure 13, panel 2). It is particularly striking that corporate and investment banking profitability came under assault on all key financial drivers - revenues, expenses and capital structure-with no offsets.

\section{A. Business Model Response}

Banks have made substantial adjustments in bank business models in the wake of the GFC. Profitability across all categories of business models are lower than pre-crisis, with the largest decline in returns found in investment bank and corporate bank models, which were hardest hit in the crisis and faced the most significant regulatory tightening.

Most G-SIBs have increased their emphasis on consumer banking, highlighted by the increase in relative revenue share, and some have shifted toward wealth management. There has been a broad reduction in the share of corporate and investment banking and markets businesses (Figure 14).

In response, eight G-SIBs have altered their business mix sufficient to migrate to a different business model. (Figure 15). The dominant shift has not been from corporate toward consumer banking, but toward universal banking as banks seek to diversify revenue sources. This finding is consistent with other recent empirical work (see Kok et al 2016).

\footnotetext{
${ }^{9}$ US regulators have articulated a capital adequacy framework based on a concept they call total loss-absorbing capacity. European bank supervisors use a similar framework based on 'minimum requirement for own funds and eligible liabilities,' or MREL.
} 

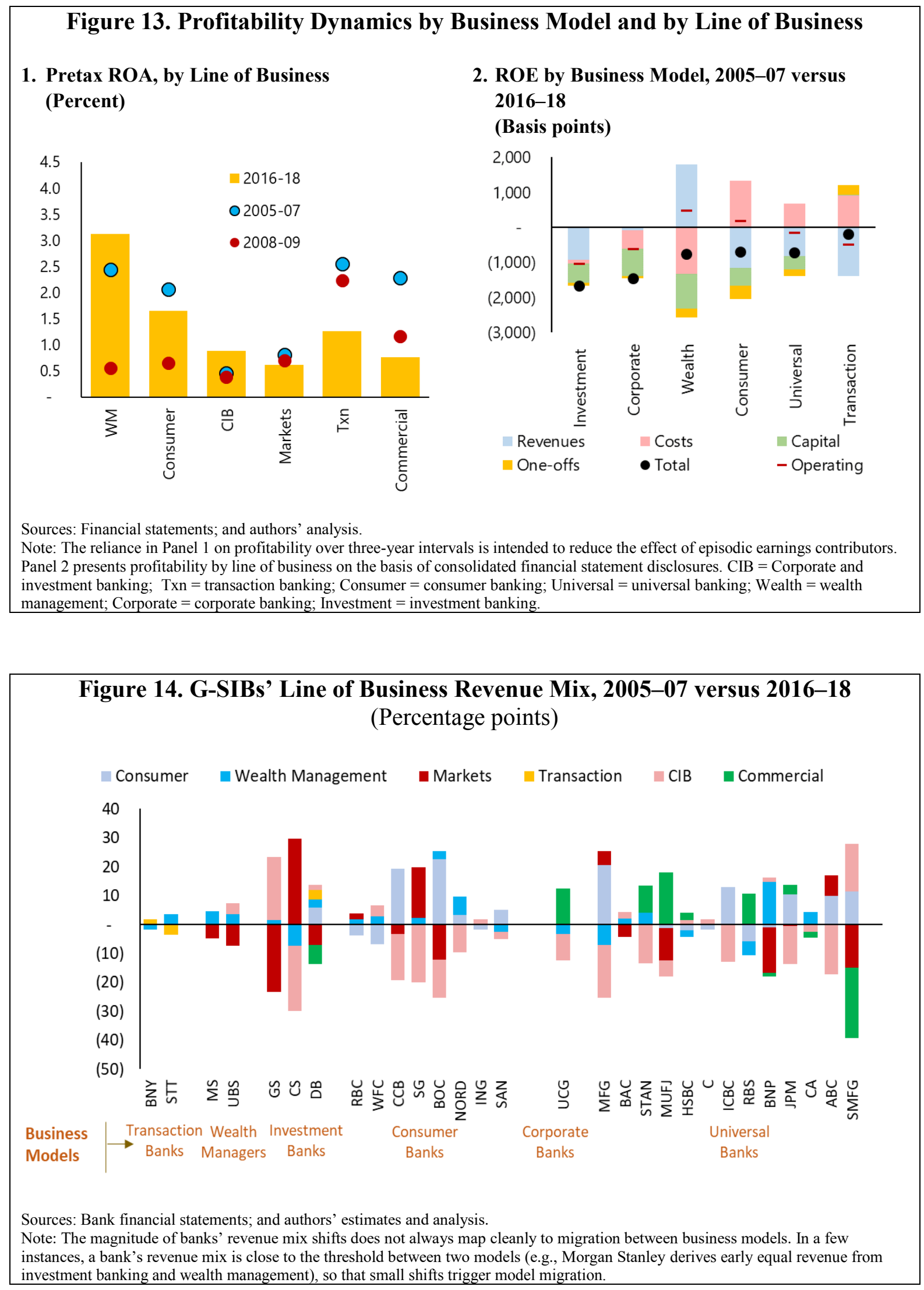
Figure 15. G-SIBs: Migration between Business Model during the Post-Crisis Period

\begin{tabular}{|lllc|}
\hline Bank & Previous Model & Latest Model & $\begin{array}{c}\text { Transition } \\
\text { Year }\end{array}$ \\
\hline Bank of America & Personal Fin. Svcs. & Universal Bank & 2010 \\
\hline JPM & Corporate Bank & Universal Bank & 2009 \\
\hline Morgan Stanley & Investment Bank & Wealth Mgmt & 2012 \\
\hline HSBC & Personal Fin. Svcs. & Universal Bank & 2007 \\
\hline Royal Bank of Scotland & Personal Fin. Svcs. & Universal Bank & 2015 \\
\hline Credit Agricole & Personal Fin. Svcs. & Universal Bank & 2015 \\
\hline Credit Suisse & Corporate Bank & Investment Bank & 2013 \\
\hline Bank of China & Universal Bank & Personal Fin. Svcs. & 2016 \\
\hline
\end{tabular}

Sources: Bloomberg Finance L.P.; S\&P Capital IQ; and authors' analysis.

While some banks have shifted business models, others have sought to strengthen lines of business within their core competencies. Banks that are strong in attractive business lines seek to increase their concentration in those areas. Wealth managers have further shifted their revenues toward the wealth management business lines, de-emphasizing corporate banking and markets. Consumer banks are increasingly focusing on their more profitable consumer business lines by reducing corporate banking and markets business lines. Banks focused on increasingly difficult businesses adapt by shifting toward strategically 'adjacent' businesses (sharing a common customer base or capabilities) consistent with the bank's core business strategy. Investment banks that lost markets businesses aim to add revenues from corporate banking (common customer base) and wealth management (common markets capabilities) (Figure 16, panel 1). As Figure 16, panel 2 illustrates, banks recognize that the profitability of a business line varies widely among banks, likely in line with their specific competences. Some are successful even within difficult business, and some lose money in businesses with healthy average returns.

\section{Figure 16. Line of Business Trends}

1. Change in Line of Business Revenue Contribution to Revenues, by Business Model (Percentage points)

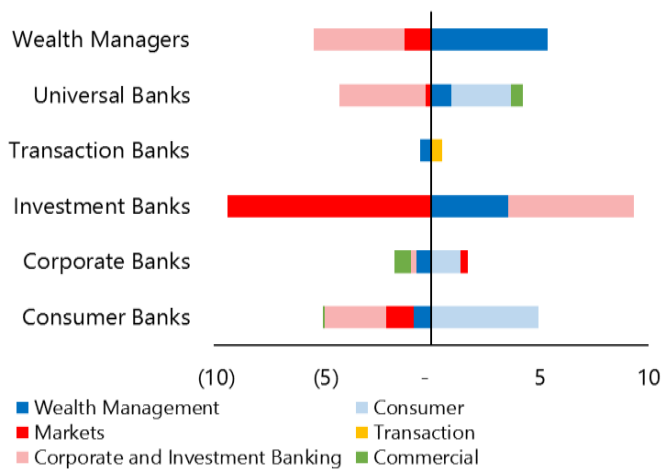

2. Pretax ROA by Line of Business: Average and Individual Banks

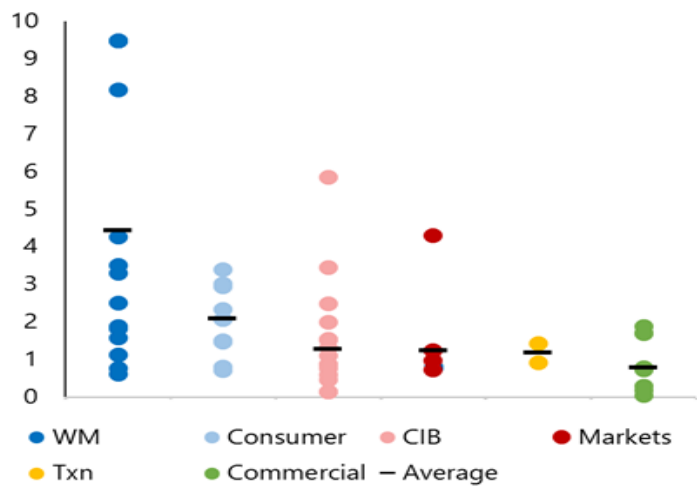


Following a period of adjustment, our methodology suggests, most GSIBs' business models stabilized by the end of 2010, and banks' focused more on consolidating strength within established business lines. This contrasts with more aggressive strategic change over the precrisis period, arguably fostered by higher growth and profitability and much higher incidence of transformative acquisitions and divestitures (Figure 17, panels 1 and 2). Expansion through acquisitions sometimes proved a costly form of business model adjustment and posed significant management challenges. Acquisition volume slowed sharply since the beginning of the financial crisis, and divestures supported adjustment. G-SIBs' assets have also plateaued after a rapid growth in balance sheet size leading into the crisis.

\section{Figure 17. G-SIB Strategic Stabilization: Sharp Slowdown in Aggregate Growth and in Acquisitions and Divestures}

1. Aggregate Assets and Revenues, 2002-2018

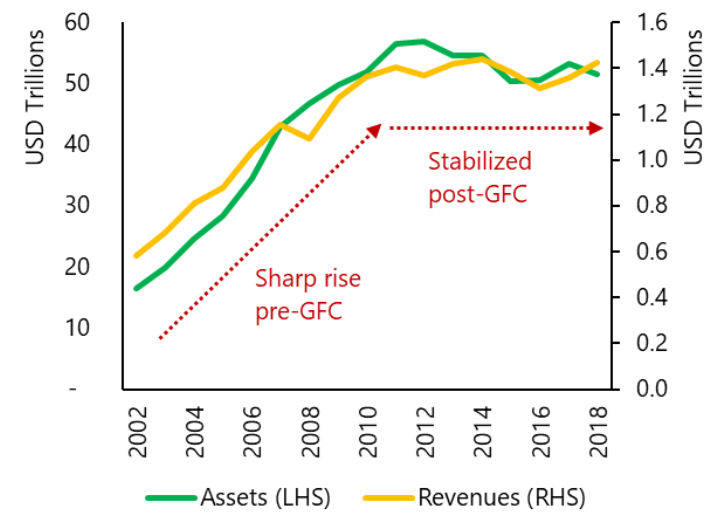

2. Acquisition and Divestiture Value, 2000-2018
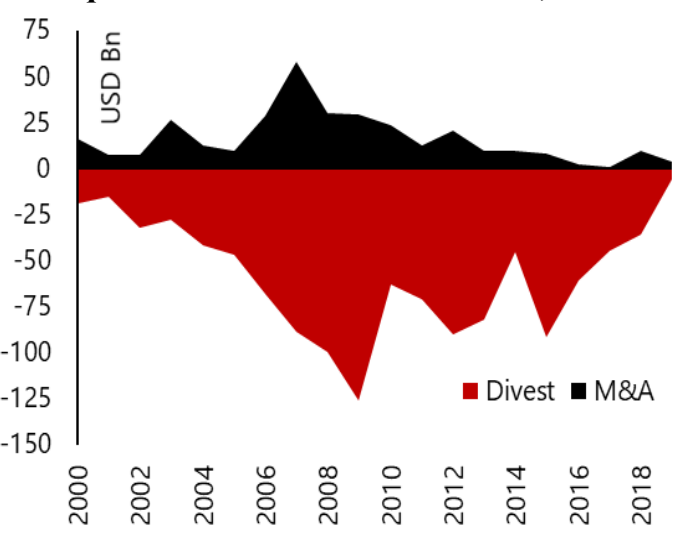

Sources: Dealogic; SNL; and IMF staff calculations.

In addition to shifts across lines of business, banks have adjusted within business lines. Most significant has been a shrinkage in balance sheet usage for warehousing risk related to capital market activities. An index of market risk intensity for G-SIBs has declined by roughly half between its peak in 2008 and 2018, particularly among US and European G-SIBs (Figure 18, panel 1). Investment banks have seen sharp reductions in market risk intensity, while wealth managers have reduced their exposures even more aggressively, (Figure 18, panel 2). Both global and regional G-SIBs (as defined in earlier in this section) have aggressively reduced their positions (Figure 18, panel 3). By this measure, regulation has achieved its intended impact. The GFC highlighted systemic risks associated with excessive market risk-taking, and regulators have taken a range of actions to moderate risk-taking and to mitigate its effects. ${ }^{10}$

\footnotetext{
${ }^{10}$ Important changes in regulation were taken, penalizing leverage, along with reforms to market structure, for example moving derivative trading to centralized platforms and clearing and settlement.
} 


\section{Figure 18. G-SIB Market Risk Intensity}
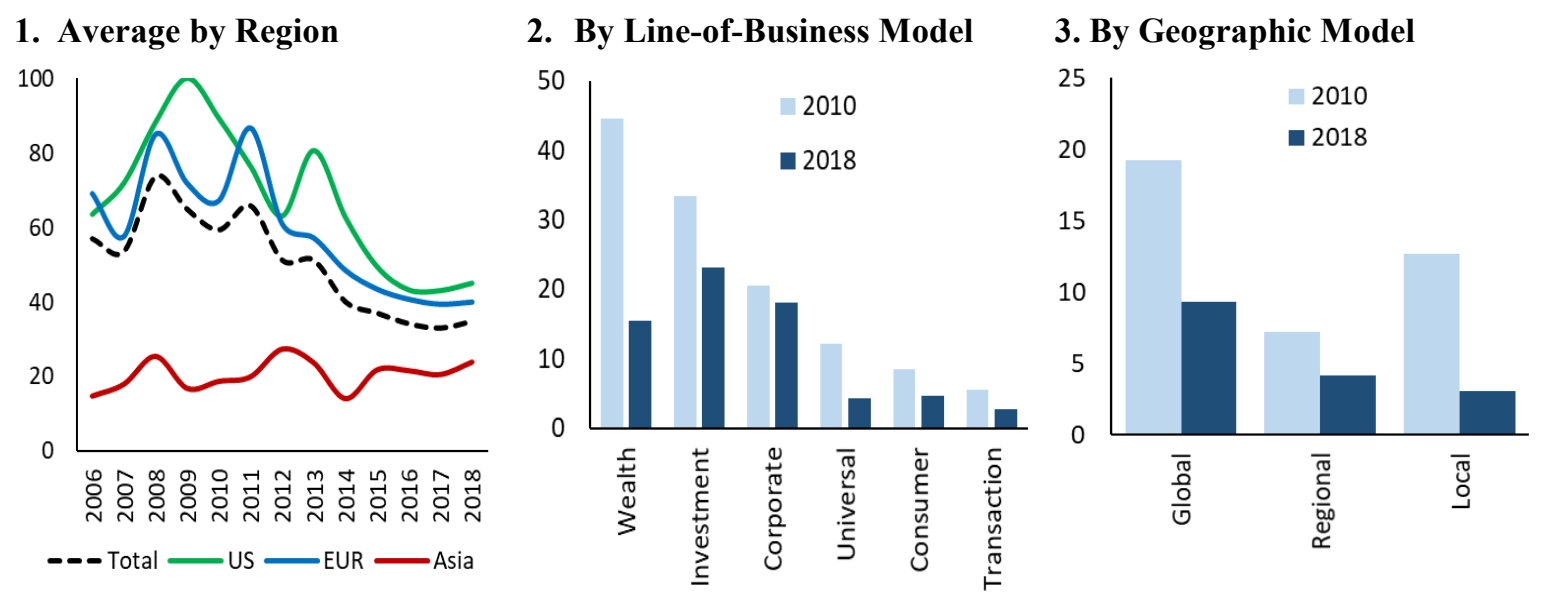

Sources: Bank financial statements; Bloomberg Finance L.P.; SNL Analytics; and authors' estimates and analysis.

Note: The market risk intensity index combines normalized values (scaled 0 to 100 across all banks and all years) for four metrics: (1) market risk-weighted assets (RWA) as a percent of total RWA; (2) Level 3 assets (illiquid and difficult-to-value positions) as a percent of total assets; (3) Notional amount of derivatives outstanding, as a percent of total assets; and (4) total value-at-risk (VAR) as a percent of total RWA. The underlying indices for banks, by region, are presented in Annex 3.

These business model adjustments, in part propelled by regulatory reform, have strengthened the banking systems and reduced systemic risk. After a period of low return on equity, overall profitability is improving. Figure 19 highlights that returns across most business models are expected (on investment analysts' median forecasts) to improve over the next few years, reflecting both lower one-off earnings hits and expected improvements in ongoing operations. ${ }^{11}$ However, some business models, such as investment banking, and some individual G-SIBs continue to struggle with very weak underlying profitability, pointing to continuing need for restructuring. ${ }^{12}$

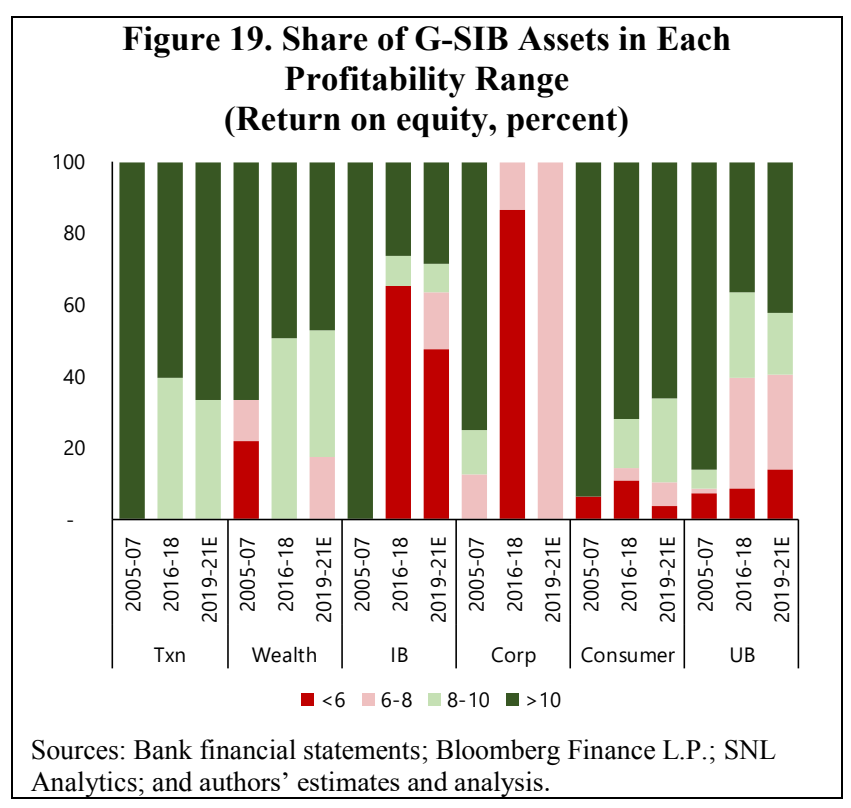

\footnotetext{
${ }^{11}$ Some improvements in earnings outlook are premised on expectations of rising interest rates and widening net interest margins, which may turn out to be overly optimistic.

${ }^{12}$ For example, Deutsche Bank, recently announced a major restructuring (closure of major business lines, large headcount reductions, major restructuring charges). Following a decade in which many G-SIBs have endured wrenching changes, the process of strategic adjustment is not yet complete.
} 


\section{B. International Focus}

Has business model adjustment led to a decline in G-SIBs' provision of international financial services? There have been concerns that economic factors and regulatory reforms might lead to a retrenchment in cross border provision of services. Proponents of this view (Forbes et al 2014; Cerutti and Claessens 2014, Cerutti and Zhou 2017), point to a sharp and sustained decline of cross-border bank lending, ${ }^{13}$ and flag possible causes ranging from banks' capital shortages, the effects of unconventional monetary policy, and regulations.

We use a broader measure of internationalization, summing the degree of internationalization of loans, deposits and revenues. ${ }^{14}$ By this measure, G-SIBs as a group have seen only a gradual decline in overall focus on international credit and services (Figure 20, panel 1). Indeed, G-SIB's banking subsidiaries (outside their home markets) have been much more stable than cross-border credit, so the reported decline in direct cross-border lending is partly compensated by increased lending from banks' foreign offices (branches and subsidiaries outside their home markets) (Lambert et al, 2015).

Within this overall picture, there have been substantial shifts in share of international credit. US banks initially retrenched into domestic operations in the immediate aftermath of the GFC, and later delivered superior returns. European G-SIBs have actually increased their international focus very slightly from an already elevated level (consistent with the increasing shift by HSBC, Santander and other large European banks toward local offices outside their home markets). Asian banks have increased their internationality focus, particularly since 2011, mainly due to Japanese banks seeking higher returns abroad.

As with line-of-business developments, shifts in international focus appear consistent with a search for enhanced profitability. Banks from regions with poor domestic profitability, for whom international operations appear relatively attractive (Japan, Europe and the United Kingdom) have maintained or increased international focus; while the US banks, whose international subsidiaries are less profitable than their domestic operations, have retrenched from international banking (Figure 20, panel 2). The exception is Chinese banks, which have internationalized despite their lower overseas profitability, but this may reflect long-term aspirations to build global footprints. In addition, they could also be looking to diversify their exposures across countries to reduce risks (Duijm and Schoenmaker 2017).

By business model, most of the decline in international focus was driven by consumer banks, universal banks with large consumer operations, and transaction banks. Investment banks, corporate banks, and wealth managers have remained more stable in their international focus

\footnotetext{
${ }^{13}$ Cross-border lending in this report is as defined in the BIS international banking statistics and does not include local lending by international banks' foreign subsidiaries and branches.

${ }^{14}$ Specifically, we measure G-SIBs' overall international focus as the sum of three indicators: (1) revenues outside the home region as a share of total revenues; (2) international loans (or assets where loans data are not available) as a percentage of total loans; and (3) foreign deposits as a percentage of total deposits. All of these measures are on a globally consolidated basis based on geographic revenues in consolidated filings and crossborder loans and foreign deposits in G-SIB scoring submissions.
} 
(Figure 20, panel 3). The global G-SIBs remained highly international, while regional and local banks have seen a decline in the degree of internationality (Figure 20, panel 4).

\section{Figure 20. G-SIBs: Measures of Internationalization}

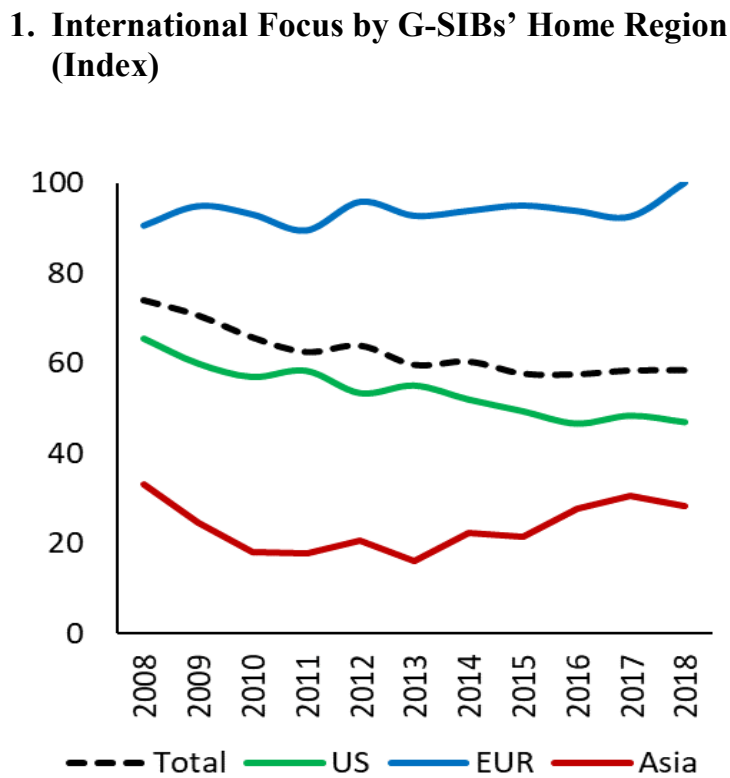
2. Return on Assets: Foreign and Domestic Subsidiaries
(Percent)

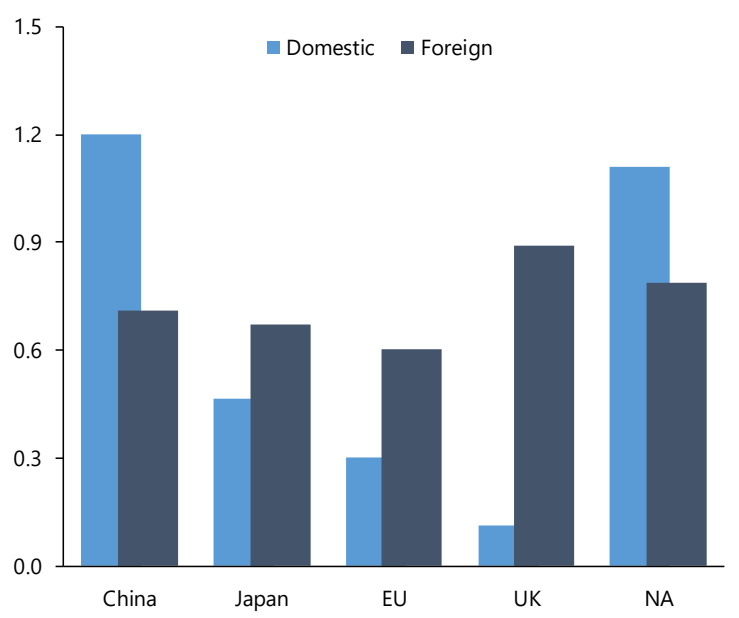
3. International Focus by G-SIB's Business Model
(Index)
4. International Focus by G-SIB's Geographic Orientation
(Index)
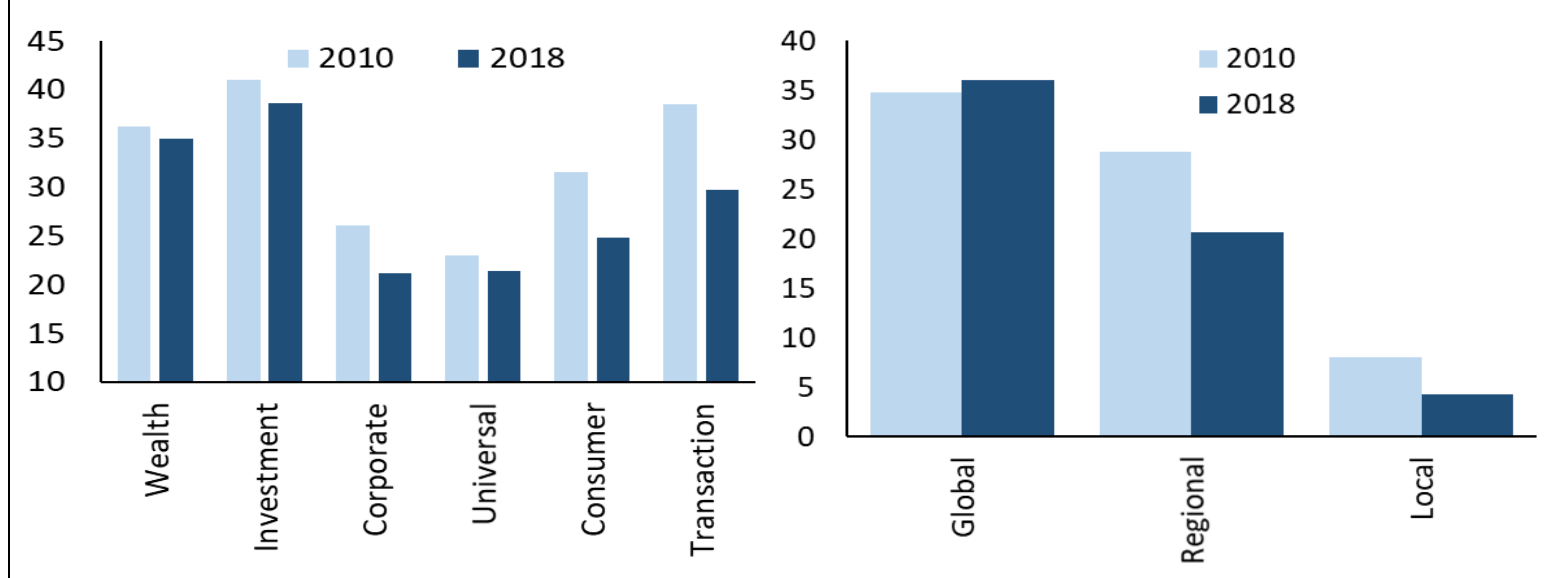

Sources: Bank financial statements; and authors' estimates and analysis.

Note: International focus in panels 1,3, and 4 is as defined in footnote 7 and is based on consolidated information. Panel 2 presents return on assets (2016-18 averages) of domestic and foreign subsidiaries because this is the best available basis for comparison. Banks' consolidated reporting generally does not include after-tax return on assets for domestic and for international operations based on a sample of 255 domestic and 679 international subsidiaries of G-SIBs. 


\section{Emerging Pressures on International Banking Models}

This section considers challenges to the two main international banking models introduced in Section II, the international wholesale and international PFS models. In wholesale banking, we highlight pressures on the international branch model by which G-SIBs manage the crossborder liquidity management and provision of credit. International retail banking, conducted largely through foreign subsidiaries, is more robust but is also challenged. In contrast to earlier sections, which classify business models on the basis of consolidated global information, this section focuses on sub-consolidated entities (subsidiaries or branches).

\section{A. International Wholesale Banking Model: Challenged}

The international wholesale banking model, generally used to serve international corporate and institutional clients, is typically structured as a network of country branch entities linked financially and legally to home country parents. This structure provides flexibility to allocate liquidity and book credit efficiently (economizing on balance sheet and capital) across countries in response to client needs and financial opportunity. Balance sheet 'due from' (i.e., lending to overseas affiliates) and 'due to' (borrowing from related parties) positions measure of funding and credit flows 'intra-group' between country branches and group related entities. The magnitude of intra-group balances differs sharply between international banks overseas branch and subsidiary operations (Figure 21, panels 1 and 2).

\section{Figure 21. Intra-Group Transfers by US Offices of Foreign Banks}

\section{US Branches of Foreign Banks (Billions of US dollars)}

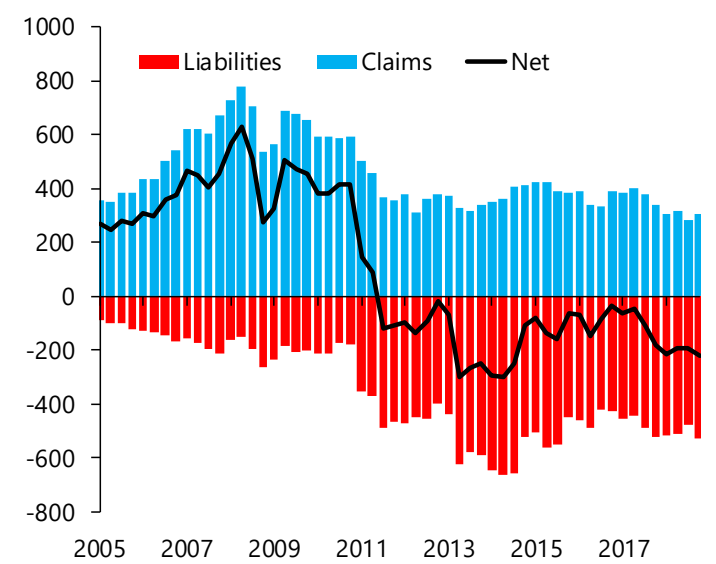

\section{US Subsidiaries of Foreign Banks} (Billions of US dollars)

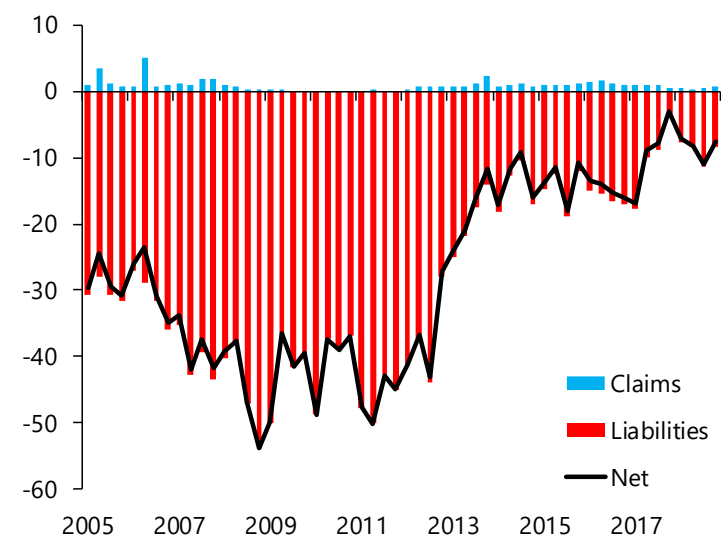

Sources: FFIEC; and Federal Reserve Board.

Note: As of end-2018. These charts include all foreign bank branches in the United States, not only G-SIBs. Claims and liabilities are expressed from the perspective of international branch operations rather than home country parent.

Over the past several years, branches' intragroup positions have been either shrinking on a gross basis - that is, both gross due from and due to are declining - or have shifted toward net borrowing vis-à-vis overseas affiliates. The US, UK and Hong Kong-highly developed 
banking systems and important nodes of the international credit system - all show declines in gross intragroup borrowings relative to total assets (Figure 22, panel 1).

The declines in gross due from and due to positions in some jurisdictions (notably the US, UK and Hong Kong) indicate that foreign branches have become less interconnected with their related parties. Global cross border intragroup flows have also declined on a flow basis over much of the post-crisis period, consistent with shrinkage in key countries' gross intragroup positions (Figure 22, panel 2). Furthermore, branches in most countries that provide information register a shift toward net intra-group borrowing (Figure 22, panel 3).

Why is this occurring and what are the consequences? This may reflect local supervisors' desire to reduce banks' scope to extend credit across borders, both to avoid losses and to conserve liquidity for domestic deployment. Some regulators have begun to implement 'structural initiatives' that increase the perimeter and strength of 'subsidiarization' and 'ringfencing' measures, essentially bringing foreign bank operations within (or closer to) the national regulator's oversight and control. ${ }^{15}$ (Gambacorta and van Rixtel 2013). Examples include the establishment of an Intermediate Holding Company Law and 'combined US operations' (CUSOs) in the United States; and in Europe, the EU's Intermediate Holding Company framework and 'ring-fencing' provisions such as Vickers. Beyond these 'structural' measures, host country supervisors are also taking steps to extend the perimeter of resolution planning and operational liquidity requirements to include foreign entities. US regulators, for example, in 2018 mandated that several large foreign bank operations in the United States issue resolution plans that include estimates of two operational liquidity parameters - Resolution Adequacy and Provisioning (RLAP) and Resolution Liquidity Execution Need (RLEN). ${ }^{16}$ US have also started in 2018 to require resolution plans of the most systemic foreign bank branches. In 2019, the Federal Reserve proposed to consider imposing direct liquidity requirements on the US branches of foreign banks.

\footnotetext{
${ }^{15}$ Host country regulators have legitimate incentives to tighten restrictions on branch liquidity management. Branches' standalone balance sheets are more fragile than subsidiaries' (less capital and more dependent on wholesale funding), and branch funding that readily flows across borders may not be forthcoming when the local branch needs it. However, these efforts, particularly if not carefully coordinated, could impair the effectiveness of the international wholesale model.

${ }^{16}$ Under RLAP, a bank measures stand-alone liquidity of each material entity to ensure that liquidity is readily available to meet deficits of a 30-day period. RLEN establishes an appropriate plan to balance pre-positioning of liquidity within each entity and available HQLA from the parent.
} 


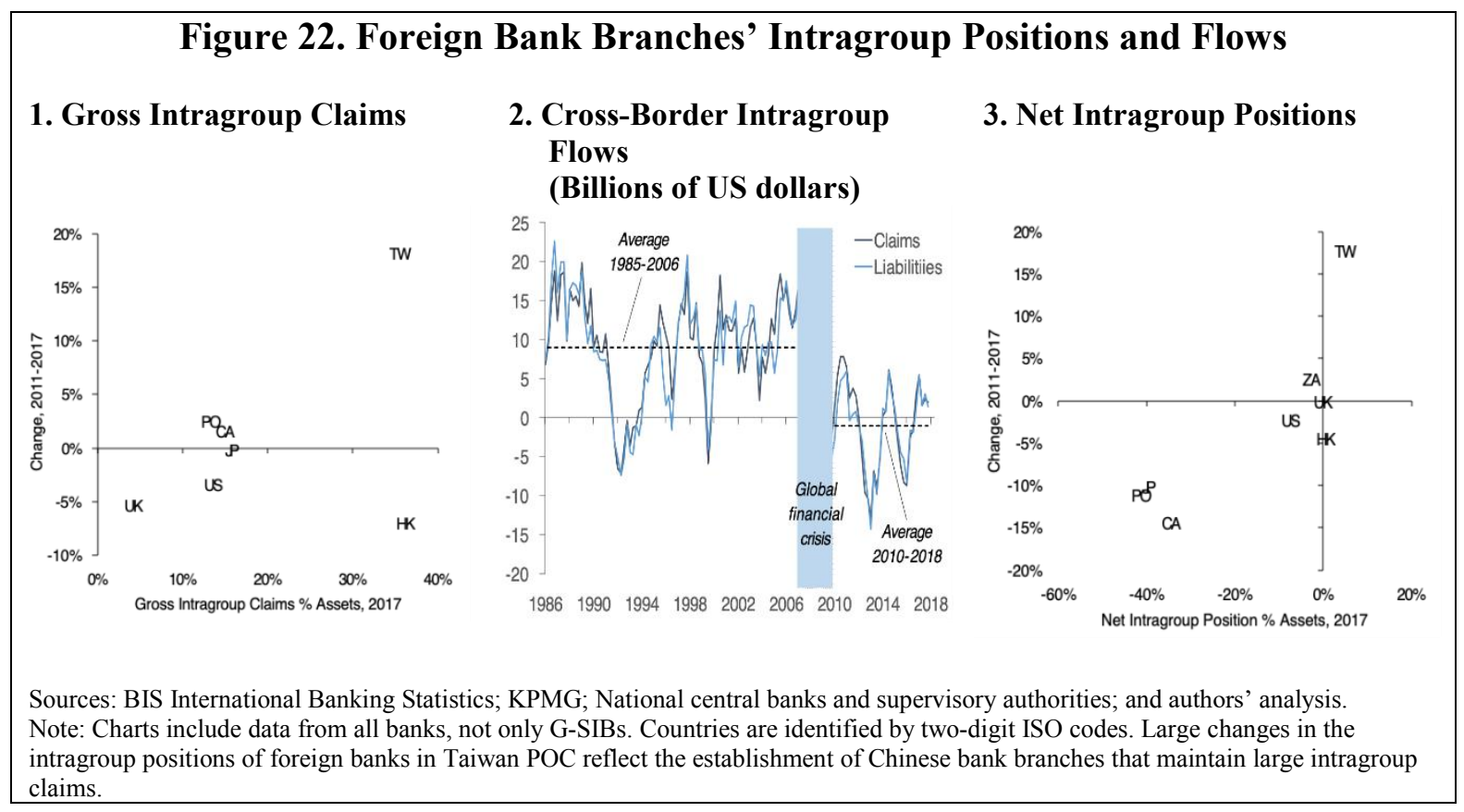

Increased pressure for local branches to build liquidity and either reduce interconnectedness (gross relationships) or risk exposures (shift toward net borrowing) with respect to their parent groups could reduce impair branches' balance sheet efficiency and international banks' ability to accommodate multinational customers' demand for flexible cross-border services. These forces, if they continue and strengthen, could pose a fundamental challenge to the international wholesale banking business model as it currently operates.

\section{B. International Consumer Banking—Lower Profitability than Domestic Incumbents}

G-SIBs from most regions report that overseas bank subsidiaries ${ }^{17}$ generate higher returns on average than their domestic banking businesses (Figure 20, panel 2). This is probably because most of their G-SIBs' international banking subsidiaries operate in developing banking systems with relatively higher margins.

Nonetheless, local players in host countries are gaining in experience, and these competitive pressures on GSIBs are likely to build over time. Using the same G-SIB bank subsidiary sample, we note that G-SIB's foreign bank subsidiaries are less profitable than domestic incumbents (Figure 23, panel 1) (see also Quoirez et al 2017). This contrasts with earlier research that, over the period 1995 to 2009, foreign banks on average generated higher profitability than domestic incumbent banks in emerging economies (Claessens and van Horen 2014).

\footnotetext{
${ }^{17} \mathrm{We}$ focus on international and domestic banking subsidiaries to represent retail banking because these operations tend to be relatively skewed toward retail and small business banking. We have excluded brokerage operations; and wholesale banking business is conducted mainly through branch networks.
} 


\section{Figure 23. G-SIBs' Overseas Bank Subsidiaries Average Performance Against Domestic Peers} 1. G-SIB banking Subsidiaries: ROA Compared
to Domestic Incumbents

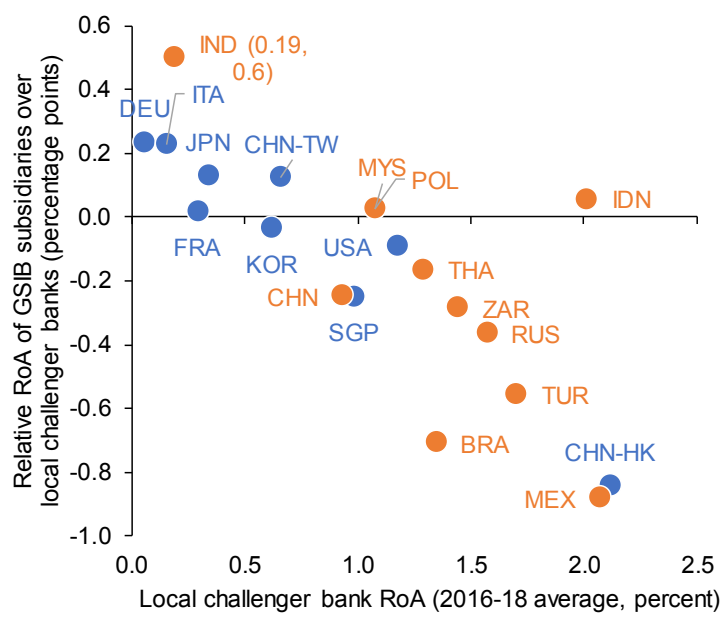

Sources: SNL; and authors' estimates.

Note: RoA measured as 2016-18 averages. Blue dots in panel 1 indicate developed economies; orange dots are emerging economies.
2. Decomposition of Difference in ROA between Domestic Banks and Foreign Bank Subsidiaries

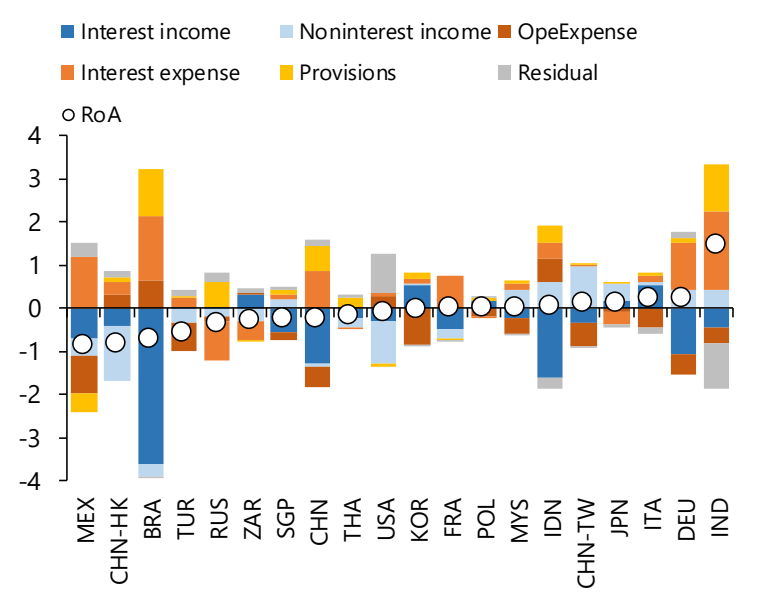

The source of G-SIBs' profitability shortfall is puzzling and deserves further investigation. A plausible hypothesis is that G-SIBs offer high-value services and superior risk management but suffer from higher funding costs (weaker local funding franchise) and higher operating expenses (low scale) relative to larger domestic incumbents. However, this hypothesis is not supported by the evidence. G-SIBs' bank subsidiaries generate relatively lower gross interest income but also lower interest expense and operating expense. In other words, they underperform on margins, but outperform on credit costs and efficiency (Figure 23, panel 2). G-SIBs' lower profitability may stem from a balance toward (relatively low margin) US dollar intermediation and lower involvement in higher-margin local currency business.

\section{Conclusion}

In the aftermath of the GFC, the global financial system - underpinned by global banks (GSIBs) - underwent watershed changes in regulation and dramatic shifts in the market, economic, and financial environment. In order to better understand how these changes might impact the provision of financial services (the role of global banks in supporting growth) while protecting financial stability, an important aspect is to understand how banks themselves are adapting their business models and adjusting lines of business to the new market realities.

This paper offers a novel taxonomy of bank business models through which banks, policy makers, and market analysts may gain insights into the evolving architecture of the global financial system. The approach aligns our taxonomy with those used by banks themselves, 
allowing us to measure shifts in bank strategies and business models consistent with those of banks in the sample, as well as changes in the way banks conduct business within business lines and their geographic footprint. This bottom-up approach also allows for a direct mapping of changes at the bank level with the architecture of the global financial system as a whole and offers the following observations.

Banks have made substantial adjustments in bank business models in the wake of the GFC. Profitability across all categories of business models are lower than pre-crisis with the largest decline in returns found in investment bank and corporate bank models, which were hardest hit in the crisis and faced the most significant regulatory tightening. In response, eight GSIBs (over one quarter) have altered their business mix sufficient to migrate to a different business model. Some banks have shifted business models shift from market-based services toward personal financial services. The dominant shift has been from corporate banking and markets towards consumer banking and wealth management. At the same time, consumer banks are increasingly focusing on their more profitable consumer business lines by reducing corporate banking and markets business lines. More generally, as banks have sought to diversify revenue sources, a number of banks have moved toward a more universal approach in providing financial services.

These changes in bank business models and in the provision of services along the various lines of business have broadly been in line with the thrust of strengthened regulation aimed at reducing systemic risk. This is particularly evident in the provision of capital market services. At the consolidated group level, there has been a broad shrinkage in balance sheet use for warehousing risk related to capital market activities. Using measures developed in this paper, market risk intensity for G-SIBs has declined by roughly half between its peak in 2008.

An important pillar of a well-functioning global financial system is the flow and activity of cross border lending and credit of which G-SIBs play a key role. Overall, G-SIBs as a group have mostly maintained their international presence and activities, as captured by our measures of internationalization, although there has been a good deal of substitution among banks. This provides some evidence that unintended consequences of diminished international activity in credit and lending have been avoided, despite higher regulatory burdens on GSIBs and a more difficult market environment, including competition from nonbanks, and low interest rates.

Adjustment in bank business models are ongoing and there are new challenges to entity structures and funding of models for organizing international activities of global banks, due in part to increasing regulatory focus on liquidity and resolution requirements. The international wholesale model may be most vulnerable given its reliance on the flexible cross-border flow of wholesale funding among international branches. Subsidiarized models appear less vulnerable, as they already rely almost entirely within nationally segregated structures for funding. However, the paper finds that G-SIBs' international subsidiaries are less profitable than domestic incumbents in many host countries, particularly in emerging economies. In the absence of a clear competitive advantage, declining PFS banking margins in these markets - a frequent by-product of financial deepening in emerging banking 
systems - poses an increasing challenge to international PFS banking models. These structural trends will need to be closely monitored for how they may impact the liquidity of global markets, the fungibility of local liquidity pools, and the resilience of the global financial system to shocks. 


\section{ANNEX 1. LiST OF G-SIBS}

G-SIBs are identified based on size, interconnectedness, cross-jurisdictional activity, impact on financial institution infrastructure (for example, the payments system), and complexity (Basel Committee on Banking Supervision 2014). The list of G-SIBs considered in the analysis are those identified in 2016, and their domicile, is in Table A.1 below.

\begin{tabular}{|c|c|c|}
\hline \multicolumn{3}{|c|}{ Table A.1. Banks in Sample } \\
\hline Region & Bank Acronym & Bank Name \\
\hline \multicolumn{3}{|l|}{ China } \\
\hline $\mathrm{CHN}$ & $\mathrm{ICBC}$ & Industrial and Commercial Bank of China \\
\hline $\mathrm{CHN}$ & CCB & China Construction Bank \\
\hline $\mathrm{CHN}$ & $\mathrm{BOC}$ & Bank Of China \\
\hline $\mathrm{CHN}$ & $A B C$ & Agricultural Bank Of China \\
\hline \multicolumn{3}{|l|}{ Japan } \\
\hline JPN & MUFJ & Mitsubishi Ufj Financial Group \\
\hline JPN & MFG & Mizuho Financial Group \\
\hline JPN & SMFG & Sumitomo Mitsui Financial Group \\
\hline \multicolumn{3}{|c|}{ Europe ex UK } \\
\hline$\overline{N L D}$ & ING & Ing Groep \\
\hline FRA & BNP & Bnp Paribas \\
\hline FRA & CA & Credit Agricole \\
\hline FRA & SG & Societe Generale \\
\hline DEU & DB & Deutsche Bank \\
\hline ITA & UCG & Unicredit \\
\hline ESP & SAN & Banco Santander \\
\hline SWE & NDA & Nordea Bank \\
\hline $\mathrm{CHF}$ & UBS & Ubs Group \\
\hline $\mathrm{CHF}$ & CS & Credit Suisse Group \\
\hline \multicolumn{3}{|c|}{ United Kingdom } \\
\hline 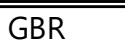 & "HSBC & Hsbc Holdings \\
\hline GBR & BARC & Barclays \\
\hline GBR & RBS & Royal Bank Of Scotland \\
\hline GBR & STAN & Standard Chartered \\
\hline \multicolumn{3}{|c|}{ North America } \\
\hline USA & JPM & Jpmorgan Chase \\
\hline USA & BAC & Bank Of America \\
\hline USA & $\mathrm{C}$ & Citigroup \\
\hline USA & GS & Goldman Sachs \\
\hline USA & MS & Morgan Stanley \\
\hline USA & BNY & Bank Of New York Mellon Corp \\
\hline USA & STT & State Street \\
\hline USA & WFC & Wells Fargo \\
\hline CAN & $\mathrm{RBC}$ & Royal Bank Of Canada \\
\hline
\end{tabular}


ANNEX 2. BREAKDOWN OF MARKET INTENSITY AND INTERNATIONALITY MEASURES

Figure A.2.1. Market Intensity Components by Region, and Market Intensity by Bank

Value at Risk / Total RWA

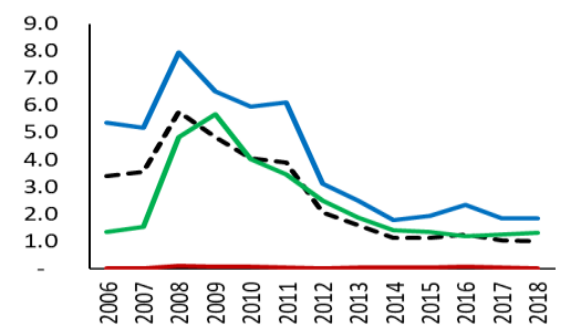

- - Total —US _ EUR —Asia

Market RWA / Total RWA

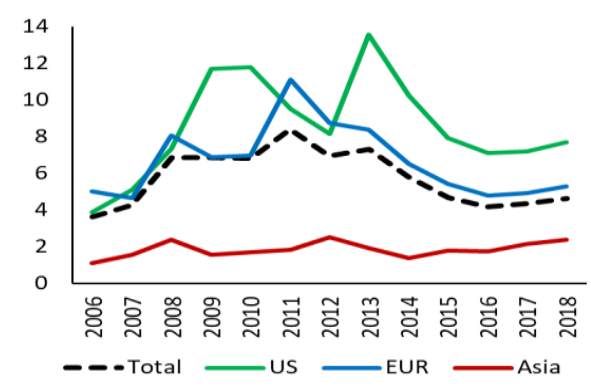

Level 3 Assets / Total Assets

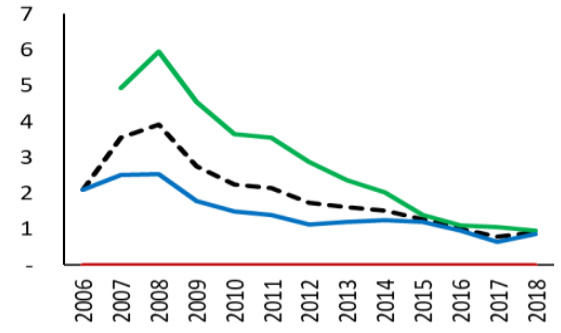

- - Total — US EUR Asia

Derivatives Assets / Total Assets

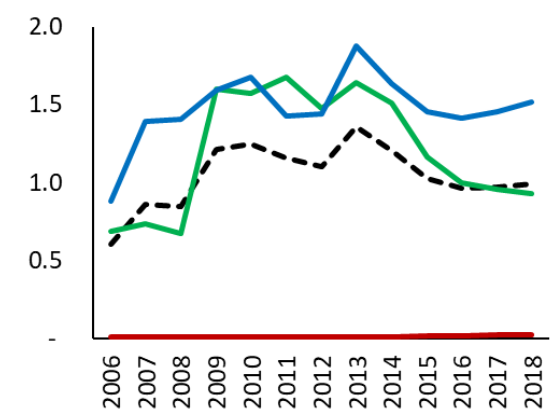

Market Intensity by Bank, 2010 and 2018

$$
\text { Index, Maximum Intensity }=100
$$$$
\begin{array}{llllll}
- & 20 & 40 & 60 & 80 & 100
\end{array}
$$

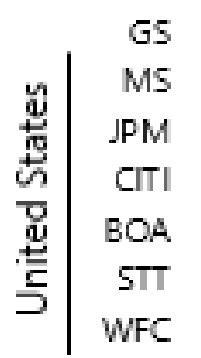

BNY

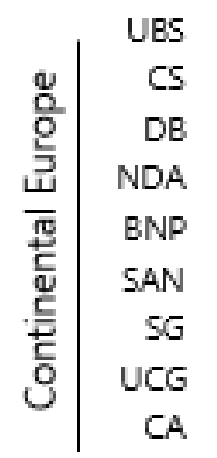

ING
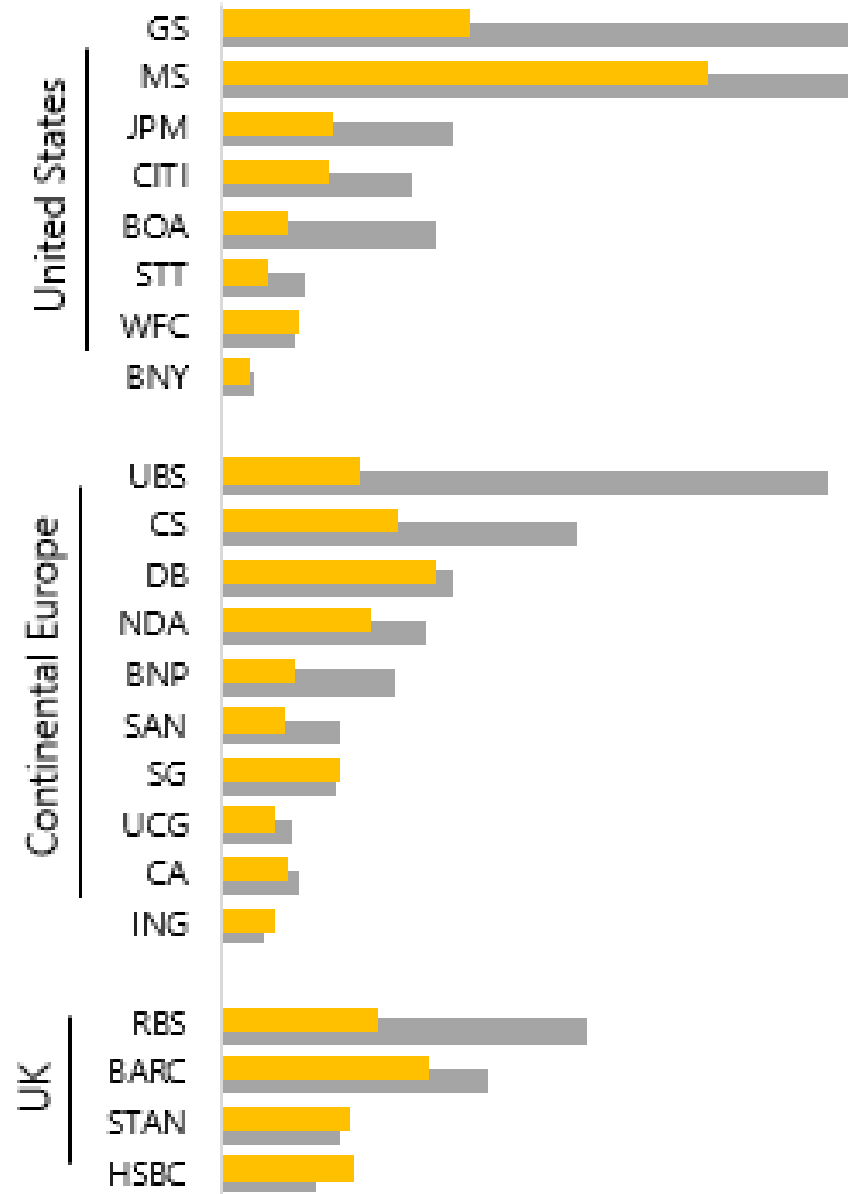

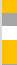
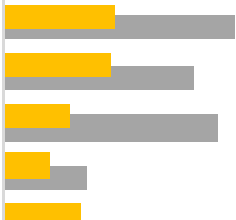

a
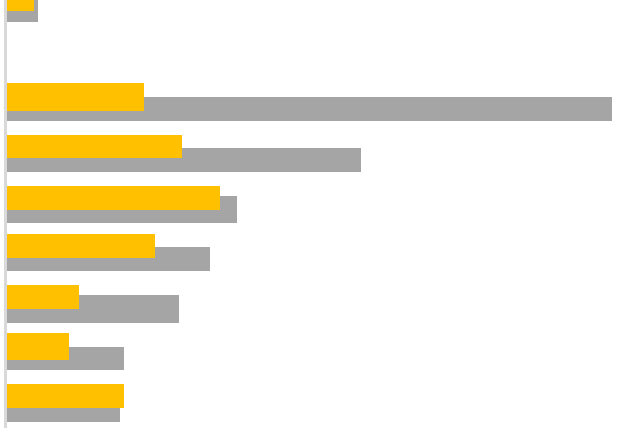

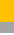

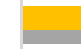

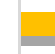

(1)

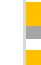

STAN

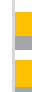

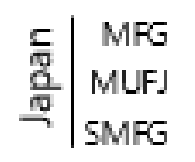

$2018-2010$

$\frac{\mathfrak{G}}{\mathrm{C}} \mid \begin{gathered}\mathrm{I} B \mathrm{BC} \\ \mathrm{BOC} \\ \mathrm{ABC} \\ \mathrm{CCB}\end{gathered}$

- - Total —US —EUR —Asia

Sources: Bank financial statements; and authors' estimates and analysis. 
Figure A.2.2. Bank Internationality Components by Region and Individual Bank

Proportion of Revenues from Non-Home Regions

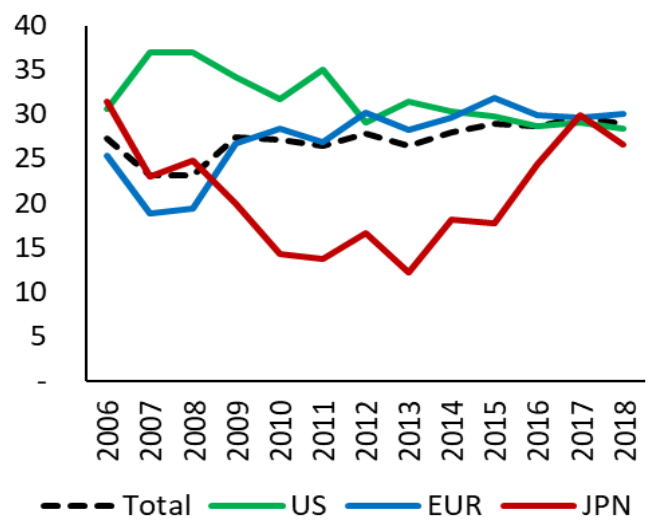

Proportion of International Loans

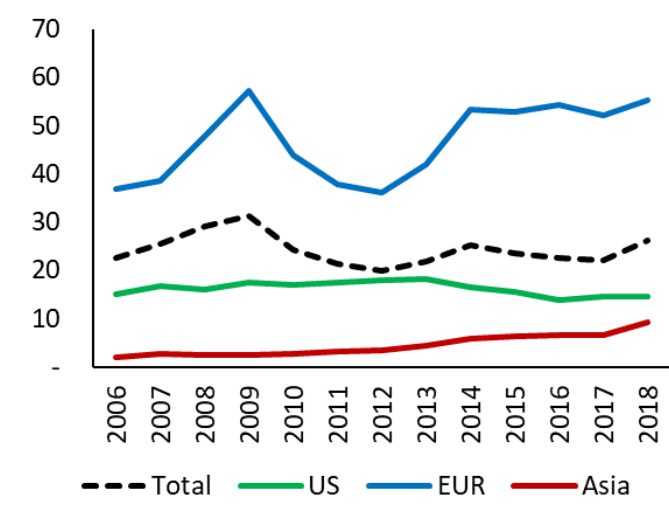

Proportion of Deposit Funding from NonHome Regions

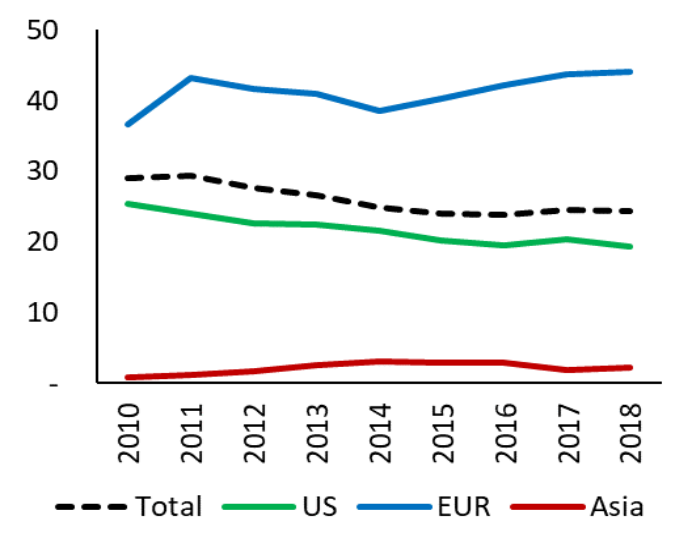

Degree of Internationality by Bank, 2010 and 2018

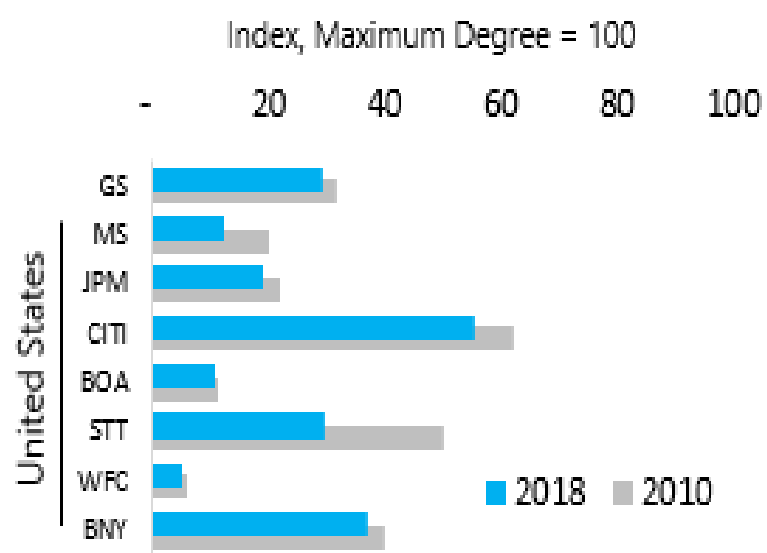

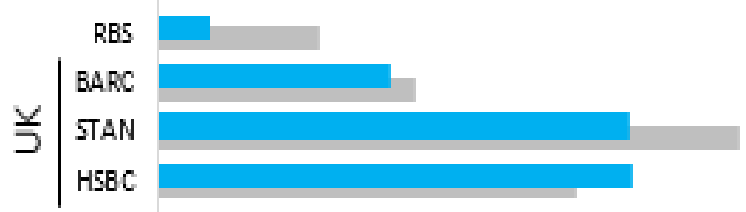
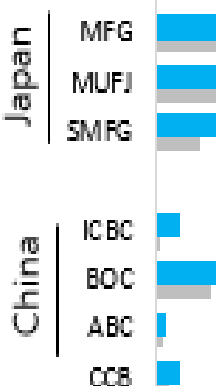

$\infty \mathrm{Cs}$

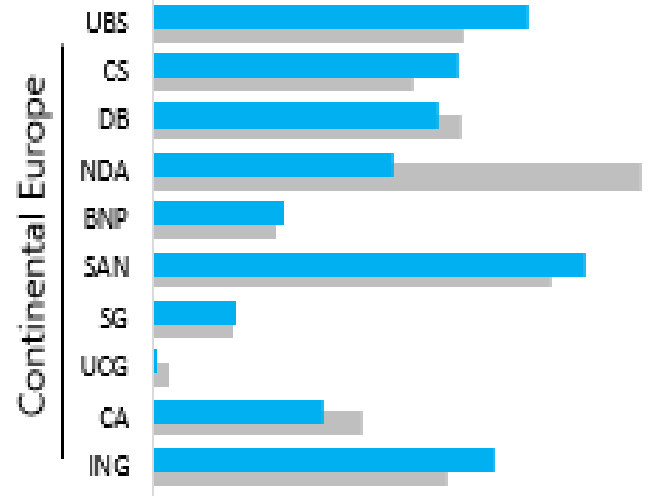




\section{Annex 3. Group Structure Measure}

1. Data on group structure include 970 subsidiaries for all G-SIB. The raw list of subsidiaries covered by SNL includes around 1600 subsidiaries of all G-SIBs. Three main criteria are used for further data processing:

- $\quad$ G-SIB ownership of the subsidiary is greater than 50 percent;

- $\quad$ There is no nesting of subsidiaries. For example, if G-SIB holds 80 percent of subsidiary A which holds 100 percent of subsidiary B, then either A or B is kept, depending on whose data quality is better.

- $\quad$ There is decent coverage of key financial statement variables.

2. The subsidiaries were categorized by their nature of business into 3 groups: banking (760), markets (160), and wealth management (50). They were also categorized by geography into either domestic (270) or foreign (700) subsidiaries (whether the subsidiary is operating in the same country jurisdiction of the parent G-SIB). Note that the number of domestic subsidiaries is on the low side as SNL does not cover domestic subsidiaries of Chinese G-SIB.

3. More details on the sample are contained in the table below.

\begin{tabular}{|c|c|c|c|c|c|c|c|c|c|c|}
\hline & \multicolumn{5}{|c|}{ Foreign subsidiaries } & \multicolumn{4}{|c|}{ Domestic subsidiaries } & \multirow[t]{2}{*}{$\begin{array}{l}\text { Grand } \\
\text { Total }\end{array}$} \\
\hline & Bank & Markets & Other ${ }^{*}$ & Wealth & Total & Bank & Markets & Wealth & Total & \\
\hline Agricultural Bank of China Ltd. & 2 & & & & 2 & & & & & 2 \\
\hline Banco Santander, SA & 28 & 6 & 1 & & 34 & 2 & 2 & 1 & 5 & 40 \\
\hline Bank of America Corporation & 12 & 6 & & & 18 & 3 & 2 & 4 & 9 & 27 \\
\hline Bank of China Limited & 22 & 1 & & & 23 & & & & & 23 \\
\hline Bank of New York Mellon Corporation & 5 & & & & 5 & 4 & 5 & 2 & 11 & 16 \\
\hline Barclays Plc & 17 & 2 & 1 & & 19 & 4 & 1 & & 5 & 25 \\
\hline BNP Paribas SA & 48 & 9 & 2 & 1 & 58 & 20 & 4 & 1 & 25 & 85 \\
\hline China Construction Bank Corporation & 8 & 1 & & & 9 & & & & & 9 \\
\hline Citigroup Inc. & 45 & 6 & & & 51 & 4 & 5 & & 9 & 60 \\
\hline Credit Agricole Group & 21 & 3 & & 3 & 27 & 17 & 2 & 4 & 23 & 50 \\
\hline Credit Suisse Group AG & 10 & 8 & 1 & 4 & 22 & 3 & & & 3 & 26 \\
\hline Deutsche Bank AG & 23 & 7 & & 2 & 32 & 6 & 1 & & 7 & 39 \\
\hline Goldman Sachs Group, Inc. & 6 & 2 & & & 8 & 2 & 4 & & 6 & 14 \\
\hline Groupe BPCE & 17 & 6 & & 2 & 25 & 51 & & 3 & 54 & 79 \\
\hline HSBC Holdings PlC & 46 & 3 & 1 & 1 & 50 & 3 & & 1 & 4 & 55 \\
\hline Industrial and Commercial Bank of China & 16 & 3 & & 2 & 21 & 2 & & & 2 & 23 \\
\hline ING Groep N.V. & 13 & 1 & & & 14 & 2 & & & 2 & 16 \\
\hline JPMorgan Chase \& Co. & 17 & 6 & & & 23 & 3 & 3 & 1 & 7 & 30 \\
\hline Mitsubishi UFJ Financial Group, Inc. & 23 & 6 & & 1 & 30 & 2 & 3 & & 5 & 35 \\
\hline Mizuho Financial Group, Inc. & 12 & 1 & & & 13 & 4 & 1 & & 5 & 18 \\
\hline Morgan Stanley & 3 & 9 & & & 12 & 2 & 4 & & 6 & 18 \\
\hline Nordea Bank AB (publ) & 5 & & & 3 & 8 & 2 & & & 2 & 10 \\
\hline Royal Bank of Scotland Group Pic & 11 & 1 & 1 & & 12 & 10 & & 1 & 11 & 24 \\
\hline Societe Generale SA & 38 & 6 & 1 & 4 & 48 & 21 & 3 & 1 & 25 & 74 \\
\hline Standard Chartered Plc & 32 & 1 & & & 33 & 1 & & & 1 & 34 \\
\hline State Street Corporation & 1 & 3 & & & 4 & 3 & 1 & & 4 & 8 \\
\hline Sumitomo Mitsui Financial Group, Inc. & 19 & 3 & & & 22 & 4 & 1 & & 5 & 27 \\
\hline UBS Group AG & 9 & 5 & & 1 & 15 & 2 & & & 2 & 17 \\
\hline UniCredit SpA & 27 & 2 & & & 29 & 2 & & & 2 & 31 \\
\hline Wells Fargo \& Company & 3 & 1 & & & 4 & 6 & 6 & 3 & 15 & 19 \\
\hline Grand Total & 539 & 108 & 8 & 24 & 679 & 185 & 48 & 22 & 255 & $934^{* *}$ \\
\hline
\end{tabular}




\section{REFERENCES}

Altavilla, Carlo., Desislava C Andreeva, Miguel Boucinha, and Sarah Holton. 2019. "Monetary policy, credit institutions and the bank lending channel in the euro area," ECB Occasional Paper Series, No. 222.

Ayadi, Rym, Emrah Arbak and Willem de Groen. 2011. "Business models in European banking: A pre- and post-crisis screening," Centre for European Policy Studies.

Ayadi, Rym, Emrah Arbak and Willem de Groen. 2012. "Regulation of European banks and business models: Toward a new paradigm?” Centre for European Policy Studies.

Ayadi, Rym, Willem de Groen, Ibtihel Sassi, Walid Mathlouthi, Harold Rey and Olivier Aubry. 2016. "Which business models exist in European banking?" Draft for International workshop on financial system architecture and stability (Victoria, Canada).

Basel Committee on Banking Supervision. 2017. "Supervisory and bank stress testing: range of practices." Basel.

. 2018. "Global systemically important banks: revised assessment methodology and the higher loss absorbency requirement." Basel.

Cerutti, Eugenio and Stijn Claessens. 2014. "The great cross-border bank deleveraging: supply constraints and intra-group frictions." IMF Working Paper 180, International Monetary Fund, Washington, DC.

, and Haonan Zhou. 2017. "The global banking network in the aftermath of the crisis: Is there evidence of deglobalization?” IMF Working Paper 232, International Monetary Fund, Washington, DC.

Cetorelli, Nicola, and Linda Goldberg. 2010. "Global banks and international shock transmission: Evidence from the crisis," Federal Reserve Bank of New York Staff Report No. 446.

. 2016. "Organizational Complexity and Balance Sheet Management in Global Banks.” NBER Working Paper No. 22169.

Choi, Sangyup, and Davide Furceri. 2018. "Uncertainty and Cross-Border Banking Flows" IMF Working Paper 18/4, International Monetary Fund, Washington, DC.

Claessens, Stijn and Neeltje van Horen, 2015. "The impact of the Global Financial Crisis on Bank Globalization," IMF Economic Review 63, 868-918.

Committee on the Global Financial System. 2010a. "The functioning and resilience of crossborder funding markets." CGFS Papers, No. 37. 
.2010b. "Funding patterns and liquidity management of internationally active banks." CGFS Papers, No. 39.

De Haas, Ralph, and Iman van Lelyveld. 2010. "Internal capital markets and lending by multinational bank subsidiaries." Journal of Financial Intermediation 19: 1-25.

.2011. "Multinational banks and the global financial crisis: Weathering the storm," Norske Bank.

, and Neeltje van Horen. 2013. "Running for the exit: International banks and crisis transmission," European Bank for Reconstruction and Development Working Paper No. 124.

Duijm, Patty and Dirk Schoenmaker. 2017. "European Banks Straddling Borders: Risky or Rewarding?" Center for Economic Policy Research Discussion Paper 12159. London.

Emter, Lorenz., Martin Schmitz, and Marcel Tirpák. 2018. "Cross-border banking in the EU since the crisis: what drives the great retrenchment?" European Central Bank Working Paper Series No 2130.

Everett Mary, Peter McQuade and Michael O’Grady, 2019. "Bank business models as a driver of cross-border activities," Central Bank of Ireland mimeo (September).

Fame, Matteo and Angelos Vouldis. 2017. "Business models of the banks in the euro area," ECB Working Paper No. 2070. European Central Bank, Frankfurt.

Fiechter, Jonathan, İnci Ötker-Robe, Anna Ilyina, Michael Hsu, André Santos, and Jay Surti. 2011. "Subsidiaries or branches: Does one size fit all?" IMF Staff Discussion Note, International Monetary Fund, Washington, DC.

Forbes, Kristin, Dennis Reinhardt and Tomasz Wieladek. 2014. "Banking de-globalisation: a consequence of monetary and regulatory policies?" BIS Working Papers, No. 86.

Gambacorta, Leonardo, and Adrian van Rixtel. 2013. "Structural bank regulation initiatives: approaches and implications.” BIS Working Papers, No. 412.

, and Stefano Schiaffi. 2017. "Changing business models in international bank funding.” BIS Working Papers, no. 614.

Herzberg V and P McQuade. 2019, "International bank flows and bank business models since the crisis," Central Bank of Ireland Financial Stability Notes Vol. 2018, No. 5.

Ichiue, Hibiki, and Frederic Lambert. 2016. "Post-crisis International Banking: An Analysis with New Regulatory Survey Data.: IMF Working Paper 16/88. 
International Monetary Fund (IMF). 2017. "Getting the Policy Mix Right” Global Financial Stability Report, April.

. 2017. "Is Growth at Risk?” Global Financial Stability Report, October.

Kerl, Cornelia, and Friederike Niepmann. 2016. "What Determines the Composition of International Bank Flows?" Board of Governors of the Federal Reserve System International Finance Discussion Papers 1170.

Kok, Christoffer, Csaba More and Monica Petrescu. 2016. 'Recent trends in euro area banks' business models and implications for banking sector stability" ECB Financial Stability Review, May.

KPMG Japan. 2010 to 2017. "Foreign Banks in Japan Survey" (Multiple editions). Tokyo.

Lambert, Frederic, Pragyan Deb, Johannes Ehrentraud, Brenda González-Hermosillo, Hibiki Ichiue, Oksana, Khadarina, Win Monroe, Hiroko Oura, Martin Saldías, and Kai Yan,. 2015. "International banking after the crisis: Increasingly local and safer?" Chapter 2 of the IMF Global Financial Stability Report, April.

Lumpkin, Stephen and Mamiko Yokoi-Arai. 2017. "The conditions for establishment of subsidiaries and branches in the provision of banking services by non-resident institutions" OECD, January.

McCauley, Robert, Patrick McGuire and Goetz von Peter. 2010. "The architecture of global banking: from international to multinational?" BIS Quarterly Review, May.

, Agustin S Bénétrix, Patrick M McGuire and Goetz von Peter, 2019, "Financial Deglobalisation in Banking?," Journal of International Money and Finance, Vol. 94, June 2019

Merck Martel, Manuel, Adrian van Rixtel and Emiliano Mota. 2012. "Business models of international banks in the wake of the 2007-2009 global financial crisis." Estabilidad Financiera, Number 22.

OECD. 2017. "The conditions for establishment of subsidiaries and branches in the provision of banking services by non-resident institutions" January. Paris.

Quoirez, Lorraine, and others. 2017. “Are Retail Banks destroying risk-adjusted value by expanding overseas?" UBS Global Research. September.

Roengpitya, Rungporn, Nikola Tarashev and Kostas Tsatsaronis. 2014. "Bank business models.” BIS Quarterly Review. December.

, and A. Villegas. 2017. "Bank business models: popularity and performance," BIS Working Papers, no. 682. 